\title{
DIRECT UTILIZATION OF GEOTHERMAL ENERGY IN
}

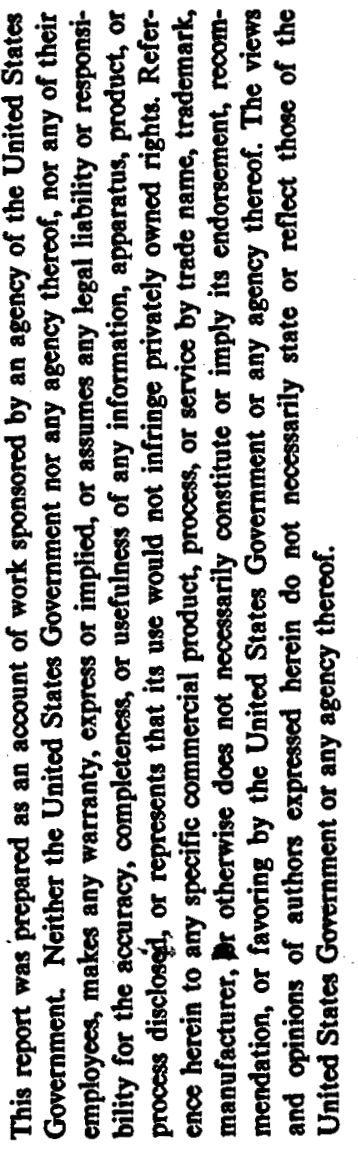
WESTERN SOUTH DAKDTA AGRIBUSINESS

Fina 1 Report

September 1983

Prepared by

Dr. Stanley M. Howard

Department of Metallurgical Engineering

South Dakota School of Mines and Technology

Rapid City, SD 57701

\author{
Sponsored by the \\ U.S. Department of Energy \\ Division of Geothermal and Hydropower Technologies \\ Washington, DC 20585 \\ Under DOE-ID Cooperative Agreement DE-FCOT-78ET28419
}




\section{DISCLAIMER}

This report was prepared as an account of work sponsored by an agency of the United States Government. Neither the United States Government nor any agency Thereof, nor any of their employees, makes any warranty, express or implied, or assumes any legal liability or responsibility for the accuracy, completeness, or usefulness of any information, apparatus, product, or process disclosed, or represents that its use would not infringe privately owned rights. Reference herein to any specific commercial product, process, or service by trade name, trademark, manufacturer, or otherwise does not necessarily constitute or imply its endorsement, recommendation, or favoring by the United States Government or any agency thereof. The views and opinions of authors expressed herein do not necessarily state or reflect those of the United States Government or any agency thereof. 


\section{DISCLAIMER}

Portions of this document may be illegible in electronic image products. Images are produced from the best available original document. 


\section{ABSTRACT AND ACKNOWLEDGEMENTS}

This project involved the direct utilization of geothermal energy for (1) space heating of farm and ranch buildings, (2) drying grain, and (3) providing warm stock water during the winter. The site for this demonstration project was the Diamond Ring Ranch north of Midland, South Dakota. Geothermal water flowing from an existing well into the Madison Aquifer was used to heat four homes, a shop, a hospital barn for cattle, and air for a barn and grain dryer. This site is centrally located in the western region of South Dakota where geothermal water is available from the Madison Aquifer. The first year of the project involved the design of the heating systems and its construction while the following years were for operation, testing, demonstrating, and monitoring the system. Required modifications and improvements were made during this period. Operating modifications and improvements were made during this period. Operating experience showed that such application of geothermal resources is feasible and can result in substantial fuel savings. Economic analyses under a variety of assumptions generally gave payback periods of less than ten years. Numerous technical recommendations are made. The most significant being the necessity of passive protection from freezing of remote geothermal systems subject to winter shut downs caused by power or equipment failure. The primary institutional recommendation is to incorporate a use for the geothermal water such as irrigation or stock watering into agribusiness-related geothermal development.

The assistance and cooperation of Frank Childs, Jon Strawn, Mike Tucker, and Robert Chappel are greatly appreciated.

This report follows a general outline which has been developed for use by all of the PON project final reports. The intent of the outline is to provide general uniformity in reporting, both in format and content, and to assure that the documentation of the project activity is complete. Since the scope of the projects vary, certain sections of the general outline will not be applicable and will be noted as such under the appropriate section heading. This will provide consistent numbering for each subject in each PON project final report.

A list of 19 PON projects which are expected to use this final report format is found in the Appendix. 
This report follows a general outline which has been developed for PoN project final reports. The intent of the outline is to provide general uniformity in reporting format and content. Since the scopes of the projects vary, some sections of the general outline may not be applicable. This accounts for gaps in the section numbering because consistent numbering has been maintained for each subject which is presented. $A$ list of PON projects which are expected to use this final report format follows. The DOE report number will be of the format: DOE/ET/XXXXX-N, where the $X$ 's are the last five digits of the contract number (given below) and $N$ is determined by the number of reports issued by the subject contract.

Contract Number

DE-FC07-78ET27054

DE-FC07-78ET27080

DE-FC07-78ET28419

DE-AC07-78ET28424 DE-FC07-78ET28441 DE-FC07-79ET27027 DE-FC07-79ET27028 DE-FC07-79ET27030 DE-nC07-79ET27033 DE-FC07-79ET27053 DE-AC07-79ET27055 DE-AC07-79ET27056

DE-AC03-78ET27154 DE-AC03-79ET27029 DE-AC03-79ET27040 DE-AC03-79ET27045 DE-AC03-79ET27047

DE-AC08-78ET27059 DE-FC08-79ET27058
Project Nane

\section{Monroe}

llaakon School

Diamond Ring Ranch

Ore-Ida Foods

st. Mary's Hospital

utah State Prison

Madison County

Pagosa Springs

Elko Heat Company

Boise

Warm Springs State Hospital

Utah Roses, Inc.

Klamath Falls

Moana, Reno

Susanville

E1 Centro

Aqua farms

T-H-S Hospital

Navarro College
DOE

Location

\section{Monroe, Utah}

Philip, South Dakota

Haakon County, South

Dakota

Ontario, Oregon

Pierre, South Dakota

Draper, Utah

Rexburg, Idaho

Pagosa Springs, Colorado

Elko, Nevada

Boise, Idaho

W.S.s.H., Montana

Sandy, Utah

Klamath Falls, Oregon

Reno, Nevada

Susanville, California

E1 Centro, California

Dos Palmas Area,

California

office

ID

ID

ID

ID

ID

ID

ID

ID

ID

ID

ID

ID

SAN

SAN

SAN

SAN

SAN

Marlin, Texas

NV

Corsicanna, Texas 
1. Howard, Dr. Stanley M., Environmental Report, Demonstration for Non-Electric Applications of Geothermal Energy, Report No. DOE/ET/27158-1, Cooperative Agreement No. DE-FC07-78ET27158 (Formerly No. ET-78-F-07-1729), August 10, 1978.

2. Howard, Dr. Stanley M., Direct Utilization of Geothermal Energy in Western South Dakota Agribusiness, First Quarterly Report, June 30, 1978 - September 30, 1978, Report No. DOE/ET/27158-2, Cooperative Agreement No. DE-FC07-78ET27158 (Formerly No. ET-78-F-07-1729), October 1978.

3. Ibid, Second Quarterly Report, October 1, 1978 - December 31, 1978, Report No. DOE/ET/27158-3, January 1979.

4. Ibid, Third Quarterly Report, January 1, 1979 - March 31, 1979, Report NO. DOE/ET/27158-4, April 1979.

5. Ibid, Fourth Quarterly Report, April 1, 1979 - June 30, 1979, Report No. DOE/ET/27158-5, July 1979.

6. Ibid, Fifth Quarterly Report, July 1, 1979 - September 30, 1979, Report No. DOE/ET/27158-6, October 1979.

7. Howard, Dr. Stanley M., Direct Utilization of Geothermal Energy in Western South Dakota Agribusiness, Final Report, Report No. DOE/ET/27158-7, Cooperative Agreement No. DE-FC07-78ET27158-7, September 1983.

Reports are available from the National Technical Information Service U.S. Department of Commerce, 5285 Port Regal Road, Springfield, VA 22161. 


\section{PROJECT DATA SHEET}

DOE Direct-Use Geothermal PON Project

1. Project Title: Direct Utilization of Geothermal Energy in Western South Dakota Agribusiness (Diamond Ring Ranch)

Contract/Cooperative Agreement

2. Number:

3. Former No.:

5. Value:

7. Participant Share:

DE-FC07-78ET28419

ET-78-F-07-1729

$06 / 30 / 78$ to $09 / 30 / 82$

$\$ 406,098$

$\$ 253,725(62 \%)$

$\$ 152,373(38 \%)$

8. Project Application: Use existing (1959) $152^{\circ} \mathrm{F}, 170 \mathrm{gpm}$ artesian flow from Madison aquifer to heat 6 structures, to run 700 bushel/hr grain dryer and for drinking (2066 ppm TDS). System has plate heat exchangers, 2 circ. loops and surface discharge.

9. Project Location: Haakon County, central SD, 50 miles west of Pierre, SD

10. Well Name/Loc: Bar-N Ranch well/Sec 31, T5N, R24E (drilled 1959)

11. Peak Heat Load: 2.26 Million Btiu/hr

12. Annual Heat Load: $\quad 4.74$ Billion Btu/yr (load factor $=23.9 \%$ overall)

13. Simple Payback (Cash): 8.0 years ( $2.5 \mathrm{mo} / \mathrm{yr}$ grain drying)

14. Project Status: Operational. Repaired leaks and installed BTU meters and recirculation loop antifreeze to make operational for 81-82 heating season. New owner very interested in system after some neglect during selling period.

15. Principal Investigator:

16. Firm:

17. Address :

18. Telephone:
Dr. Stanley M. Howard

South Dakota School of Mines and Technology

500 East St. Joseph Street, Rapid City, South Dakota: 57701 605-394-2341

Other Participants:

19. Firm/Activity: RE/SPEC, Inc.

20. Address: Box 725, Rapid City, SD 57709

21. Phone/Contact: 605-343-7868/Thomas Zeller

22. Firm/Activity:

23. Address :

Gerlach \& Ebert Plumbing and Heating/Construction

24. Phone/Contact: 1104 Jackson Blvd., Rapid City, SD 57701

25. Firm/Activity: Joe Verlin

26. Address: Kalispel1, MT

27. Phone/Contact: 406-883-2859

/Resource \& Application Owner 
(This page intentionally blank.) 
1. INTRODUCTION............................................. 1

1.1 Department of Energy Project Opportunity Notice Program...... 1

1.2 Demonstration Projects.................................... 2

1.3 Diamond Ring Ranch Demonstration Project..................... 2

1.3.1 Project Goals................................... 2

1.3.2 A Pre-Project Background............................ 3

1.4 Project Scope................................................. 4

1.5 Growth Potential........................................... 5

2. SUMMARY.................................................. 6

2.1 Project Development.................................. 6

2.2 Economic Result....................................... 7

3. CONCLUSIONS AND RECOMMENDATIONS........................... 8

3.1 Technical............................................... 8

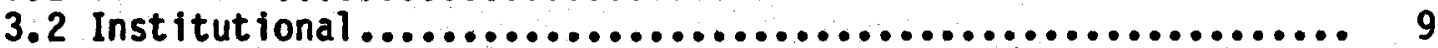

3.3 Economic ........................................... 9

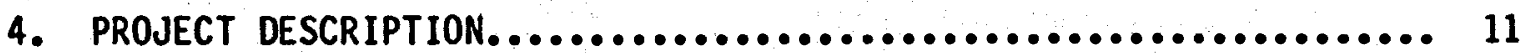

4.1 Task Breakdown........................................ 11

4.2 Organization and Participants............................ 11

4.3 Cost Breakdown........................................ 11

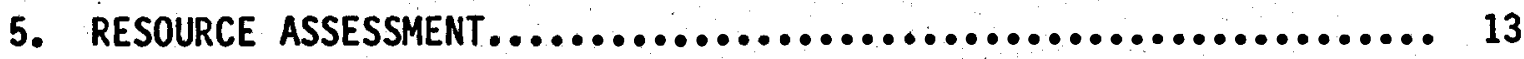

5.1 Pre-Project Assessment............................. 13

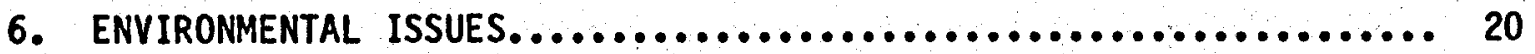

7. INSTITUTIONAL ISSUES AND PERMITS......................... 24

7.1 Private......................................... 24

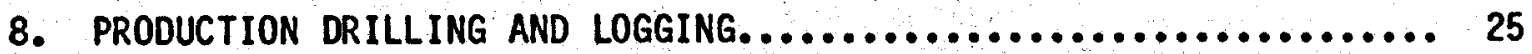

9. RESOURCE TESTING.................................... 26

9.1 Apparatus.......................................... 26

9.2 Tests Conducted......................................... 27

10. DISPOSAL DRILLING AND LOGGING............................ 31

11. DISPOSAL TESTING.................................. 31 
12. APPLICATION ANALYSIS $\ldots \ldots \ldots \ldots \ldots \ldots \ldots \ldots \ldots \ldots \ldots \ldots \ldots \ldots \ldots \ldots \ldots \ldots \ldots \ldots$

12.1 Technical $\ldots \ldots \ldots \ldots \ldots \ldots \ldots \ldots \ldots \ldots \ldots \ldots \ldots \ldots \ldots \ldots \ldots \ldots \ldots \ldots \ldots \ldots . \ldots . \ldots \ldots$

12.2 Economic........................................ 33

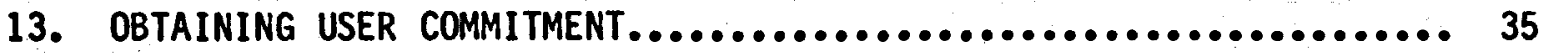

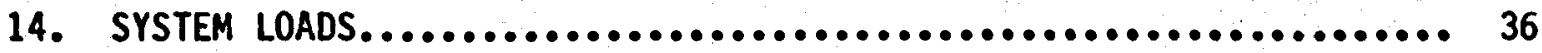

14.1 Peak ............................................ 36

14.2 Annual .................................................. 36

14.3 Load Factor........................................ 37

14.4 Fuel Replaced.................................... 37

15. PRODUCTION SYSTEM DESIGN.............................. 38

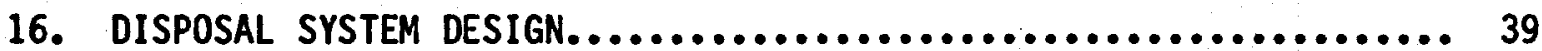

16.1 Selection Process.................................... 39

16.2 Design......................................... 39

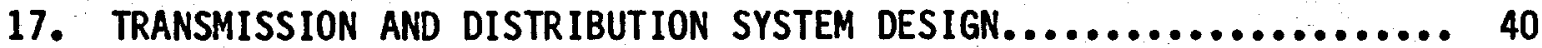

17.1 Selection Process................................... 40

17.2 Design............................................. 40

17.2.1 General Description.......................... 42

18. SYSTEM DESIGN..................................... 44

18.1 Selection Process.................................... 44

18.2 General Description................................. 45

19. APPLICATION SYSTEM DESIGN........................... 47

19.1 Selection Process................................... 47

19.2 Design.......................................... 48

19.2 .2 Controls .................................... 50

19.2.3 Major Components............................. 51

19.2.5 Environmental Control and Monitoring............. 53

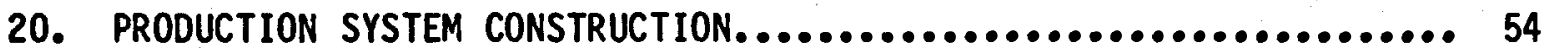

21.-24. DISPOSAL, TRANSMISSION, DISTRIBUTION, AND

APPLICATION SYSTEM CONSTRUCTION..................... 54

21.-24.1 Bidding, Selection and Contract.................... 54

21.-24.2 As-Built System................................ 55

25. SYSTEM MANAGEMENT AND ORGANIZATION..................... 56

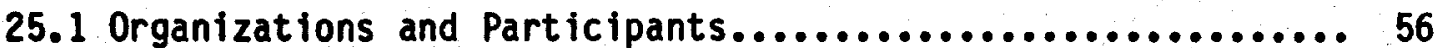

25.2 Responsibilities.................................. 56 


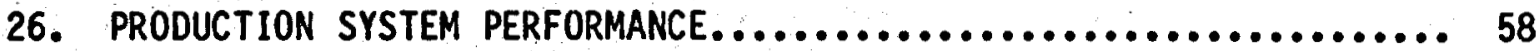

26.1 Post Construction Modification..................... 58

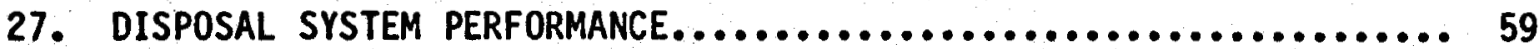

28. TRANSMISSION SYSTEM PERFORMANCE $\ldots \ldots \ldots \ldots \ldots \ldots \ldots \ldots \ldots \ldots \ldots \ldots \ldots \ldots$

28.1 Performance Summary................................ 60

28.2 Date Acquisition................................... 60

28.3 Post Construction Modification........................ 61

28.4 Operator Satisfaction............................... 61

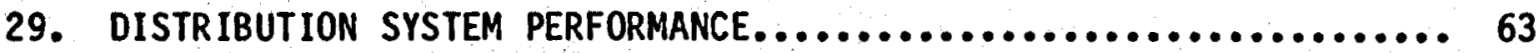

29.1 Performance Summary.................................. 63

29.2 Data Acquisition................................... 63

29.3 Post Construction Modification......................... 64

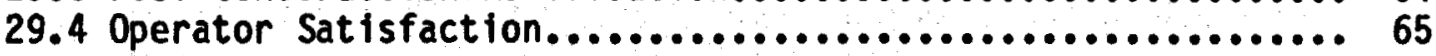

30. APPLICATION SYSTEM PERFORMANCE $\ldots \ldots \ldots \ldots \ldots \ldots \ldots \ldots \ldots \ldots \ldots \ldots \ldots \ldots \ldots \ldots \ldots \ldots \ldots$

30.1 Performance Summary ................................ 66

30.2 Data Acquisition................................... 66

30.3 Post Construction Modification......................... 68

30.4 Operator Satisfaction............................... 68

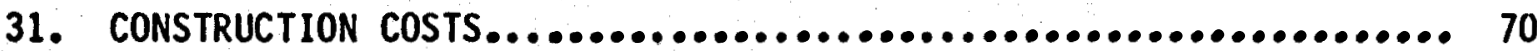

31.1 Production System............................... 70

31.2 Disposal System.................................. 70

31.3 Transmission System.............................. 70

31.4 Distribution System............................... 70

31.5 Application System.............................. 71

32. OPERATING AND MAINTENANCE COSTS $\ldots \ldots \ldots \ldots \ldots \ldots \ldots \ldots \ldots \ldots \ldots \ldots \ldots \ldots$

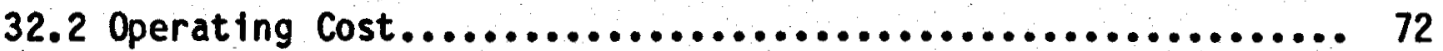

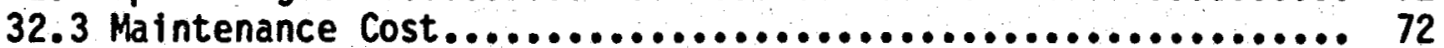

32.3.1 Rout ine.................................... 72

32.3.2 Major Component Repair or Replacement............. 73

33. SYSTEM ECONOMICS $\ldots \ldots \ldots \ldots \ldots \ldots \ldots \ldots \ldots \ldots \ldots \ldots \ldots \ldots \ldots \ldots \ldots \ldots \ldots \ldots \ldots \ldots$

33.1 Capital Costs................................... 74

33.2 Operating and Maintenance Costs...................... 74

33.4 Customer Billing.................................. 77

33.5 Analysis...................................... 77

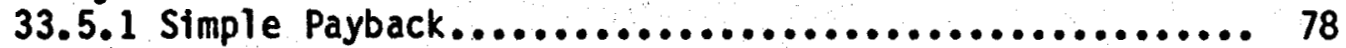

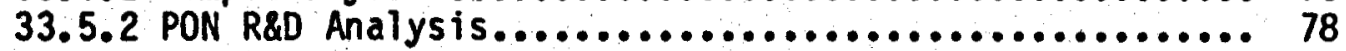

33.5.3 Other Analyses.............................. 79

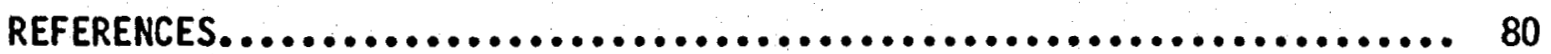


1. Location of the Project in Western South Dakota

2. Map of Hilltop Diamond Ring Ranch

3. Schedule

4. Corrosion Test Rack

5. Grain Dryer Pipeline Size - Cost Comparison

6. Schematic Diagram of Geothermal System

7. Typical Heating/Geothermal Pump Electrical Control

8. Underground Control Line Layout (New Service)

9. Furnace and Geothermal Heat Controls for the Employees Home and Mobile Homes No. 1 \& 2

10. Westinghouse Heat Pump and Geothermal Controls for the Owner's Home 11. Hospital Barn and Shop Unit Heater Power and Control Diagrams

12. Behl in Model 380 Continuous Grain Dryer Control Circuit Modifications 13. Pump Control Diagram 230 Volt (New Service)

14. Management Chart 


\section{LIST OF TABLES}

1. Weight Loss Results for the Coupon Tests Corrosion Rate in $\mu \mathrm{m} / \mathrm{yr}$

2. Major Components

3. Pre-Project Water Analysis $(8 / 8 / 78)$

4. Post-Project Water Analysis (7/26/82)

5. Summary of Space Heat Replaced

6. Operating Costs

7. Summary of Operating and Maintenance costs

8. Equivalent Annual Operating and Maintenance costs

9. Value of Space Heating Replaced

10. Total Fuel Savings per Year

11. Total Savings Realized by the Use of the Geothermal System

12. Simple Payback

13. Breakeven Time for Selected Interest Rates and 2 Months Grain Dryer Use per Year 
1. INTRODUCTION

1.1 Department of Energy Project Opportunity Notice Program

The use of geothermal energy for direct heat purposes by the private sector within the United States has been quite limited to date, yet there is a large potential market for thermal energy in such areas as industrial processing, agribusiness, and space/water heating of commercial and residential buildings. Technical and economic information is needed to assist in identifying prospective direct heat users and to match their energy needs to specific geothermal reserviors. Technological uncertainties and associated economic risks have influenced potential user perception of profitability to the point of limiting private investment in geothermal direct heat applications.

In September 1977 and April 1978, the Department of Energy, Division of Geothermal Energy (now the Division of Geothermal and Hydropower Technologies), issued two Program Opportunity Notices. These solicitations were part of DOE's national geothermal energy program $\mathrm{plan}$, which had as its goal the near-term research and development of hydrothermal resources by the private sector. Encouragement was given to municipalities and the private sector by DOE offering to share a portion of the front-end financial risk in a limited number of field experiment projects. After competitive evaluations, 23 PON projects were selected from the two Project Opportunity Notice (PON) solicitations. This is the final report for one of those PON projects.

\subsection{Demonstration Projects}

Demonstration projects receiving financial support under the DOE's PON program must resolve a number of technical and institutional problems ranging from resource exploration to retrofit and operation of the plant on geothermal energy. The technology developed in these initial projects is being made avallable to the general public and to stimulate the development of geothermal energy. 
Industrial application of geothermal energy is a relatively new concept, and carries significant potential in terms of market size and utilization factor. Utilization of geothermal energy in a process application, in comparison to space heating, has an inherent advantage in that it does not depend on climatic conditions, but rather on process load energy requirements. The industrial geothermal system can be used to its full capacity most of the time, while space heating is subject to seasonal drops.

Typically, in an industrial application, a large load is concentrated in a single facility. In contract, a district heating system uses numerous, scattered, small loads. Thus, the energy unit cost of industrial application is lower.

1.3 Diamond Ring Ranch Demonstration Project

\subsubsection{Project Goals}

The goal of this project was to demonstrate that geothermal energy could be used to provide thermal energy for space heating and grain drying at the Diamond Ring Ranch. The Ranch is located along Highway 34 approximately 50 miles west of Pierre, South Dakota. Figure 1 is a map showing the project location. Structures geothermally heated were the following:

shop
insulated hospital barn
owner's home
employee's home
two mobile homes

The location of each of these structures and the grain dryer are shown in Figure 2.

\subsubsection{Pre-Project Background}

A geothermal well at the Diamond Ring Ranch to the Madison Aquifer was completed in 1959 for the purpose of providing domestic water, 



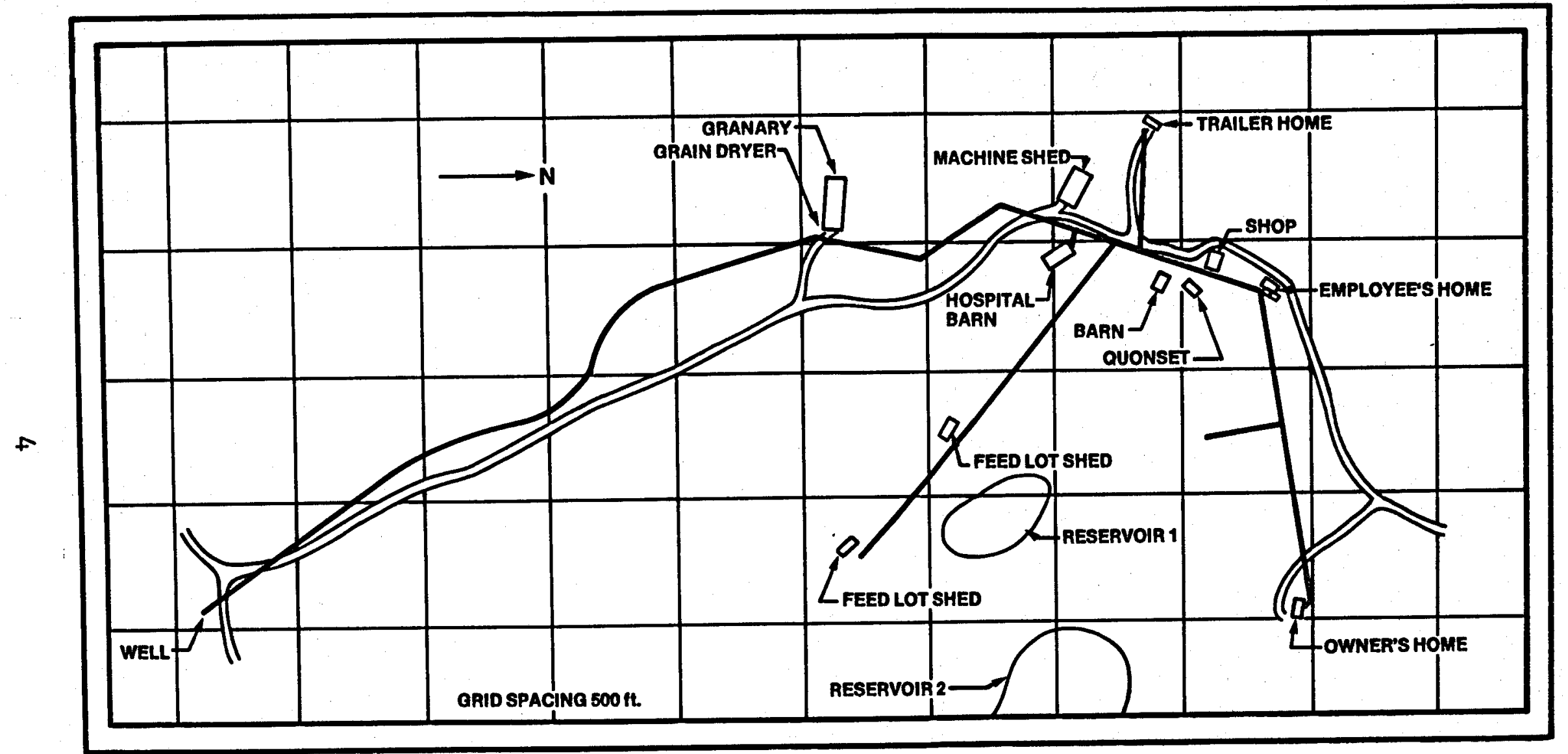

\section{HILLTOP DIAMOND RING RANCH GEOTHERMAL DEMONSTRATION}

Figure 2. Map of Hilltop Diamond Ring Ranch. 
livestock water, and irrigation water. The artesian flow from the well is at the rate of $173 \mathrm{gpm}$ and a temperature of $153^{\circ} \mathrm{F}$.

Before this geothermal project, corrosion studies were performed at the well site to determine the corrosion rate of varlous materials. This work was performed under ERDA contracts to the South Dakota School of Mines and Technologyl. The conclusion reached by that study was that stainless steel 316 would provide satisfactory resistance to corrosion.

Scaling was not found to occur within existing transmission lines however, an iron pyrite sediment did accumulate slowly in low spots of the line.

Ranch personnel had thought that some application of the geothermal heat was possible, but they did not know how to do it. The invitation to jointly submit a proposal for demonstrating the application of the geothermal energy was enthusiastically received by them.

\subsection{Project Scope}

The scope of the project changed very little from initial proposal to completion. The scope of the proposal was to provide space heating for the following structures:

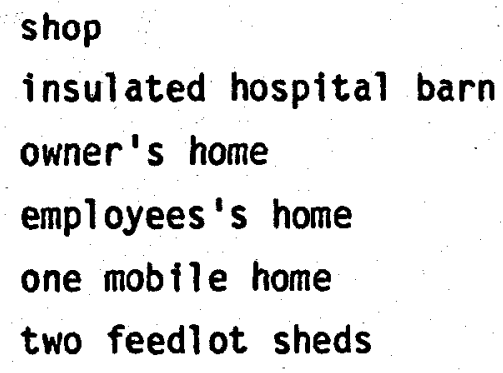

In addition, the geothermal well was to provide heat for a grain dryer. The pre-project water lines were to remain in use.

This scope was modified in three ways. First, the heating of the feedlot sheds was abandoned before construction, because the cost of heating open feedlot sheds far exceeded the expected benefit. 
Secondly, a second mobile home was added to the system to compensate for the loss of the feedlot shed application. Third, the existing water line from the well was abandoned and domestic water was drawn from the new distribution line.

\subsection{Growth Potential}

The potential for additional geothermal applications in western South Dakota's agribusinesses depends on two important economically-related points: 1) the size of the demand and 2) the existence of a geothermal well near existing potential applications. Many geothermal wells are drilled solely for a water source. In cases where the well is near existing potential applications, the cost of using the thermal energy is likely to be lower than conventional fuels. If, on the other hand, a well must be drilled, then only very large potential applications can provide adequate benefit to justify the high capital costs incurred. New wells should be considered only when applications have peak heating loads over one million BTU/hr.

In western South Dakota there are between twenty and thirty geothermal wells to the Madison. Fewer than ten are close enough to structures to be considered attractive for geothermal development. However, many small towns ranging in population up to several thousand are located over the Madison Aquifer. Also, agribusinesses will be drilling new Madison wells in the future for livestock and irrigation. The judicious placement of these new wells could also make the wells energy resources. 
2. SUMMARY

\subsection{Project Development}

This project originally consisted of using an existing geothermal well 4000 feet from the application site for space heating and grain drying. The first major change in the project was the elimination of space heating feed lot sheds because the cost of heating far exceeded the economic benefit. Originally, one large isolation heat exchanger was to be used to heat recirculating water by the geothermal water. This heated recirculating water was to heat two conventional homes, two mobile homes, a shop and a hospital barn and provide heat for grain drying. The cost of recirculating lines and pumping costs from such an isolation exchanger to the grain dryer were too great. Consequently, a second isolation exchanger was incorporated into the design for the grain dryer. This had the side benefit of allowing a smaller transmission line from the grain dryer to the space heating exchanger.

Two significant changes in the transmission system were the installation of two PVC air vent valves and an air lift break at the well head. The vent valves were necessary to prevent air pockets from building up in the pipeline and impeding flow. The air lift break at the well head was required because air from the degasser vent was lifting water from the vent stack and flooding the well head area. An air lift break consisting of a vertical 20-foot long 4-inch diameter PVC pipe was installed as the vent stack.

The only major change in the distribution system was the inclusion of antifreeze in the recirculating lines. Originally, backup power and pumping equipment was thought adequate; however, freezing during power fallures experienced in the second winter of operation showed antifreeze was required. 


\subsection{Economic Result}

The system operated as designed although some plugging of monitoring equipment was experienced. Monitoring data obtained showed the space heating system capable of saving up to $\$ 26,543$ per year and the grain dryer substantially more than that depending on usage. A typical two month per year usage would result in fuel savings of $\$ 20,784$. Payback times under most assumptions for the system were generally less than 10 years. 
3. CONCLUSIONS AND RECOMMENDATIONS

\subsection{Technical}

The following technical recommendations are made as a result of this project.

a) Geothermal heating and grain drying is technically feasible using the Madison Aquifer.

b) Geothermal heating systems in remote locations must be passively protected against freezing in the event of power or other equipment failure. This is most effectively done by requiring antifreeze in all recirculating lines exposed to freezing conditions and providing for automatic drainage of geothermal fluid transmission lines which may be subjected to freezing conditions.

c) Each space heating application should have shut-off valves on both the return and supply lines located immediatly outside each application structure so as to allow servicing of geothermal exchangers and interior distribution lines without danger of flooding the structure.

d) Filtering screens should be placed before each positive displacement flow meter.

e) No special insulation consideration is required in transmission or distribution lines buried in dry, lowconductivity soils such as the Pierre Shale.

f) Stainless steel 304 is a suitable corrosion resistant material for contact with Madison Aquifer geothermal fluid.

g) Air vents must be installed in the high points of gravity flow transmission lines.

h) Pipe thread joints between bronze circuit setters and PVC pipe therads should be inspected before installation to assure compatibility. It was found that the PVC male threads did not seal with the circuit setter threads because the circuit setter threads were too short. 


\subsection{Institutional}

The following institutional recommendation is made. To minimize the institutional and regulatory barriers to private site geothermal development, plans should be made for the use of the geothermal water not just its thermal energy. In agribusiness this is easily done by using it for irrigation or stock water.

\subsection{Economic}

The economic feasibility of a geothermal system is highly dependent upon

- the size of the thermal demand

- the transmission distance for the geothermal fluid

- the assignment of well cost to water development

- the distance between individual application sites within one system

- the development of year-round applications for the resource. In this regard, the following recommendations are made as having a major favorable impact on the economic impact on geothermal systems in agribusiness.

a) Develop the geothermal resource in concert with water development so that well costs may be shared or assigned to water development.

b) Drill production wells near the application site. This is easily done in the Madison Aquifer.

c) Develop grain drying and other such non-heating-season applications so as to increase use efficiency. 
4. PROJECT DESCRIPTION

\subsection{Task Breakdown}

This project was divided into five major tasks:

Prel iminary Design

Final Design

Construction

Operation and Monitoring

Publicity

Figure 3 shows the schedule of these tasks.

4.2 Organization and Participants

The major participants were:

Dr. Stanley M. Howard

South Dakota School of Mines and Technology

500 E. St . Joseph Street

Rapid City, South Dakota 57701

Mr. Thomas Zeller

RE/SPEC Inc.

Rushmore Industrial Park

Rapid City, South Dakota 57701

Mr. Gene Armstrong

Diamond Ring Ranch

Star Route

Midland, South Dakota 57552

Mr. Mel Gerlach

Gerlach \& Ebert Plumbing

1104 Jackson Blvd

Rapid City, South Dakota 57701 
FY -1978

FY - 1979

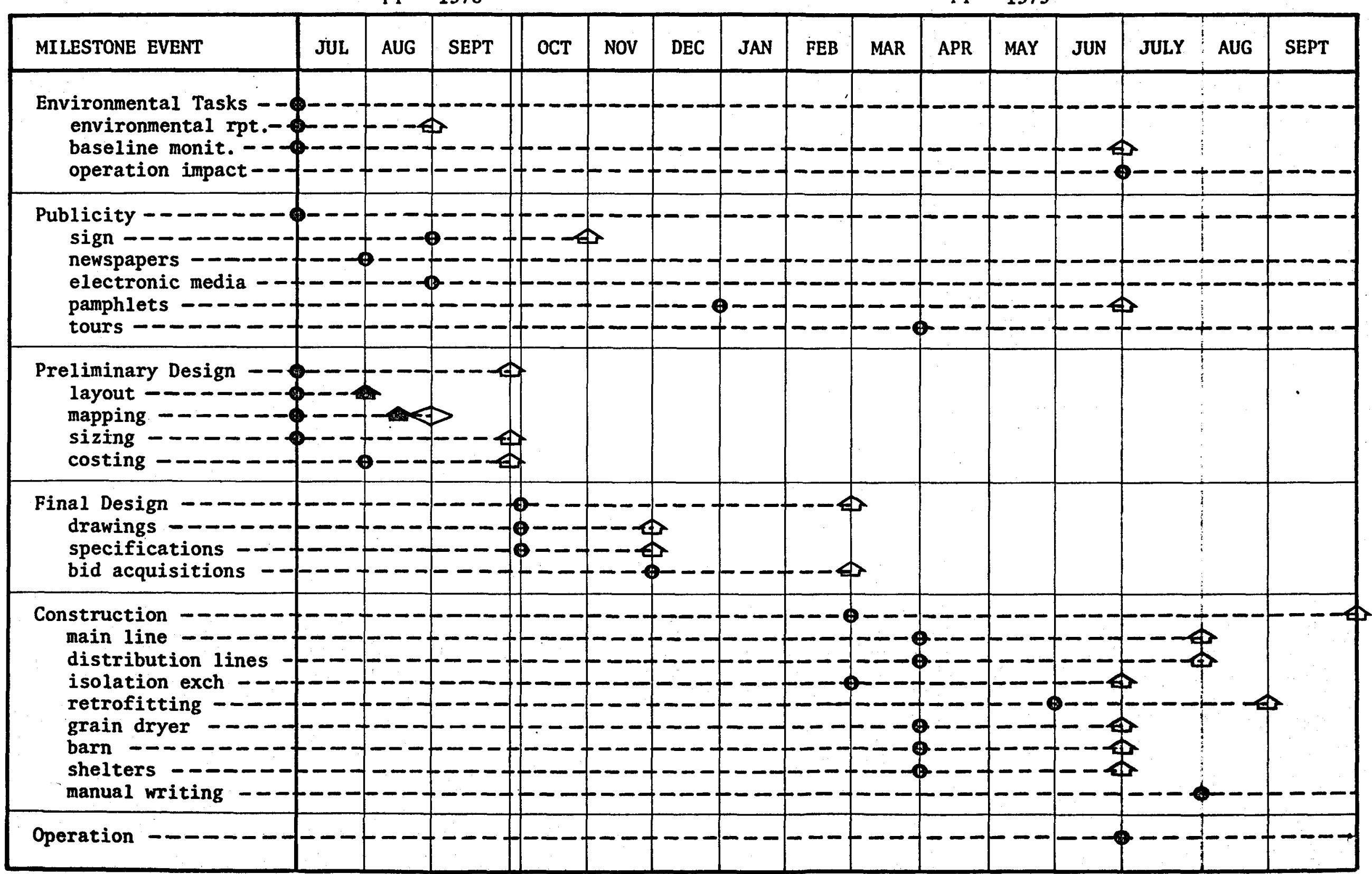

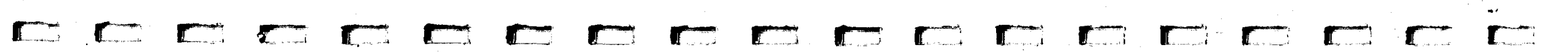


4.3 Cost Breakdown:

The cost breakdown for the project is as follows:

\begin{tabular}{lr} 
Design & $\$ 33,730$ \\
Construction & $\$ 327,227$ \\
Operation and Monitoring & $\$ 23,605$ \\
Publicity & $\$ 18,536$ \\
\hline & $\$ 403,098$
\end{tabular}

The construction cost includes $\$ 90,000$ for the value the existing well.

The total cost of the project, including cost matching, was $\$ 403,098$. The breakdown on the source of funding was:

U.S. Department of Energy $62 \%$

Diamond Ring Ranch 38\% 
5. RESOURCE ASSESSMENT

\subsection{Pre-Project Assessment}

The Madison Aquifer, or as it is locally known in the Black Hills, the Pahasapa Formation, is generally referred to as a limestone, although as has been demonstrated by Andrichuk ${ }^{2}$, Gries and Mickelson ${ }^{3}$, and others, much of the formation is actually a clean, crystalline dolomite.

The Madison carbonates, and their time equivalents elsewhere in the Rocky Mountain region, were deposited in a broad seaway which covered much of the area now occupied by the Rocky Mountains of the United States and Canada. South Dakota lies on the eastern edge of that former seaway. The formation thickens from zero along the eastern edge of the subcrop to over 1300 feet in northwestern Harding County. Further to the north and northwest, it thickens to about 2700 feet in the center of the Williston Basin in North Dakota, and to over 2800 feet in the central Montana trough 4 .

The Madison is divisible into three lithologic units, which are in ascending order the Lodgepole Member, the Mission Canyon Member, and the Charles Member. In the deeper parts of the Williston Basin, and extending into northwestern South Dakota, the Charles contains evaporite units which profoundly affect the quality of the Madison water.

Porosity in the Madison Aquifer is a combination of three types: 1) normal intergranular porosity, particularly in the dolomites, 2) joint and fracture porosity, and 3) solution openings ranging in size from slightly enlarged joints to caverns in which the drill bit may drop several feet. Permeability is affected also by the types of openings present in the aquifer. It is not suprising that well yields vary widely.

The Madison limestone is noted throughout its areal extent for large 
flows of water under high artesian pressures, and for the attendant drilling problems of well control and lost circulation.

Two episodes in the postdepositional history of the Madison Aquifer are pertinent to the understanding of its water-yielding potential. Following the retreat of the early Mississippian sea, the newly deposited carbonate terrain remained slightly above sea level for a long period of time. As a result of groundwater solution on this carbonate terrain, caverns were formed. Their ultimate collapse resulted in the formation of sinkholes. Sufficient limestone was removed by solution and erosion to produce a surface relief of many tens of feet, and the insoluble clays and chert within the formation remained behind as a blanket of red residual soil. Part of this clay was washed into the underground passages as it was formed; more was reworked and distributed over the low spots on the surface when the sea next returned to the area. Deposition of more red muds effectively sealed the top of the Madison, and much of the old solution network remained open or only partially filled with clay. Slow circulation of groundwater through these openings has continued to the present time.

The second episode pertinent to the hydrologic behavior of the Madison occurred when the Black Hills were uplifted during the Laramide Orogeny. As soon as the overlying sediments were removed by erosion, surface water was again able to enter the cavern system. Much water filters down through bare outcrops, but more spectacular infiltration occurs where streams cutting down through the limestone lose large volumes of water to sinkholes in the limestone along the creek bed. This water has sometimes carried recent alluvial material down into the old openings, but more often it has tended to remove the old clay filling from the upper part of the old cave network, and to redposit it at lower elevations. The cleaned-out openings are then enlarged by further solution. :

Because water now entering the limestone cannot all be accepted by the hydrologic system, some of it breaks back to the surface to form artesian or resurgent springs. Although the position of these springs has 
shifted somewhat as erosion progressed, the present-day sinkholes and springs are descendants of the earlier system.

The relationship between stream losses to sinkholes in the Madison Formation and the discharge from resurgent springs has been verified by researchers at the South Dakota School of Mines during ten years of stream gaging across the Madison outcrops and at various springs ${ }^{5-8}$. These records have been summarized by Rahn and Gries ${ }^{9}$, who have confirmed that the resurgent springs do serve as escape valves, returning to the surface water which cannot move into the Madison artesian system. Their calculations al so show that the amount of water returned to the surface in this manner is greater than that lost to the sinkholes along stream channels. It is concluded that an important part of the recharge to the Madison artesian system is derived from rain and snowmelt which infiltrate the outcrop area.

In addition to the visible evidences cited above, two other lines of approach indicate that the outcrops around the Black Hills constitute the recharge area for South Dakota and for the eastern Powder River Basin in Wyoming. The potentiometric data show the highest head to be at and adjacent to outcrops, and the total dissolved solids are lowest close to the outcrops.

Very little is known about the movement of the water once it enters the Madison artesian system. Except close to the outcrop area, the potentiometric surface becomes nearly flat, and no definite directions of movement can be inferred. Limited age-dating of the Madison water gives contradictory estimates of the rate of movement downward from the outcrop 10 . Swenson 11 postulated that the Madison water escapes from the system by upward leakage into the Cretaceous sandstone aquifers. Support for this hypothesis is found in the anomalous quality of Dakota water in the north central part of the state.

Very little information is available on transmissivities, storage coefficients, or specific capacities of Madison wells in South Dakota. 
The first Madison well drilled at the Rapid City Air Force Base in 1942 reported a specific capacity of $10.6 \mathrm{gpm} / \mathrm{ft}$ drawdown at a pumping rate of $426.5 \mathrm{gpm}$. At the Ben French Station of Black Hills Power and Light $C_{0}$, the No. 3 Well, completed in the Madison, had a specific capacity after a small acid treatment of $0.187 \mathrm{gpm} / \mathrm{ft}$ drawdown. After a second acid treatment, the specific capacity improved to $0.28 \mathrm{gpm} / \mathrm{ft}$ drawdown. The well was subsequently abandoned on the Wyoming side of the Black Hills, where conditions within the Madison may be presumed to be similar.

\section{Well rields}

Recorded well yields in the Black Hills area range from $80 \mathrm{gpm}$ using a pump to over $1000 \mathrm{gpm}$ free flow. It would appear from study of the randomly distributed wells in South Dakota that a discharge of 500 gpm, either natural flow or pumping, can be considered an average for a properly constructed and developed Madison well. Some wells would require acid fracturing to reach this rate of production.

\section{Well Interference}

The question of interference between closely spaced limestone wells has not been adwquately studied. Virtually no change in flow is noted at the No. 1 Madison well of the Black Hills Power and Light Co. at Osage, Wyoming when the No. 2 Well, a mile away, is heavily pumped. A test run on the two city wells at nearby Upton in June 1972 showed a drawdown on the observation well one mile away of 0.60 feet after 4 hours of pumping at 150 to $160 \mathrm{gpm}$, and a drawdown of 44.14 feet on the pumping well. There is some evidence that neither well had entirely recovered from pumping on the previous day.

A distinction has been made between temperatures obtained directly from flowing or pumping wells, and data from bottom-hole temperature recorders. Surface water temperature is slightly lower than formation temperature if the water movement to the surface is slow, and wells in long service frequently yield water a few degrees warmer than the 
figures obtained on the initial production tests.

The highest temperatures occur in the northwestern part of the state, where the Madison lies at depths of over 7000 feet with temperatures of $170^{\circ} \mathrm{F}$.

The large warm-water area in the west-central part of South Dakota is an anomaly for which there is no satisfactory explanation at present. Carda 12 has noted that the Philip, Midland, and Bar-N Ranch wells in Haakon County are the only three Madison wells within the state in which he detected Radium 226, and all three lie within the warm-water anomaly.

Madison wells are sometimes difficult to complete properly. If the red shale cap which generally overlies the Madison karst surface were always underlain by relatively solid limestone, it would be relatively simple to drill a few feet into the top of the limestone to set and cement casing. But in karst topography, mud-filled fractures and caverns may be encountered several feet or even several tens of feet below the first apparently solid limestone. These red zones may cause trouble by per mitting the well to throw out chunks of red shale. The chunks may wedge in the casing, where they restrict flow and usually cause the well to yield water with a reddish cast. Generally, setting a perforated liner after determining the extent of the cavernous area will solve the problem.

Because drillers anticipate a large flow when the first cavernous porosity is encountered, they are prone to set casing at the first sign of Madison limestone, and to take their chances on later cavern fillings.

Fortunately, limestone wells respond to acid stimulation. Acid injected under high pressures not only fractures the rock hydraulically, but enlarges the fractures as the acid is held in the rock under hydrostatic pressure. Acidizing at selected intervals, after examination of porosity logs (gamma ray and bulk density), permits 
placing the acid in relatively tight areas rather than having it all pass into the most open passages. Successive injections of small amounts of acid (3000-5000 gal) in carefully selected intervals is generally more effective than one large "shotgun" treatment. 
Geothermal water flowing from an artesian well in existence since 1959 was used to heat four ranch homes, a shop, an insulated barn, and livestock shelters and to dry grain. The construction phase began in the Spring of 1979 and ended in the Summer of 1979. The construction consisted of laying PVC pipelines connecting the wellhead to the various structures requiring heat. After the construction phase, heat was delivered to the above structures by heat extraction from the geothermal water. The geothermal water from which heat was extracted flows into an existing reservoir system used for both geothermal well and runoff catchment.

Most of the land from the wellhead to the grain drying bin area which was excavated supported the growth of native grasses. Most of the other areas were barren lands in livestock corrals or along roadways. The trenches for pipeline burial was excavated by a rotary trenching machine and was backfilled by bulldozer or front-end loader.

Water consumed for construction activities was minimal. All water was drawn from the existing well except for water to fill the recirculating line. This water was hauled from Hayes, South Dakota. The use of this water reduced scaling and corrosion problems in the recirculating loops.

The amount of trash and construction wastes was very small and was placed in the ranch's usual disposal site. No discarding of toxic or hazardous materials was experienced.

Operation

No change in the appearance of the Diamond Ring Ranch was experienced as a consequence of this project. The grain dryer built during this project employed geothermally heated air, but its appearance was not substantially different from a conventional drying system common to many farms in the region. 
There is no history of environmentally disruptive gaseous emissions from the existing well. Average annual well discharge does not exceed 50 acre feet. This amount is nearly insignificant in comparison to the capacity of the large reservoir in which the discharge is caught. This water is used for stock water and crop irrigation.

This project affected the environment in only two ways: (1) soil disturbance caused by pipeline excavation and (2) increased geothermal water discharge during some periods. Neither of these affects produced significant changes in the environment. Following are brief summaries of various environmental considerations.

\section{Regional Demography}

Figure 1 shows the population centers around the proposed site. By virute of the largeness of the Diamond Ring Ranch, the sections surrounding the site area even more sparsely populated than most rural western South Dakota areas.

Land Use

With the exception of the ranch structures, the land surrounding the site is all ranch land and corral areas. State Highway 34 runs east and west approximately one mile north of the wellhead as shown on Figure 1.

$\underline{\text { Geology }}$

The surface soil is essentially composed of weathered Pierre shale. The Pierre is essentially the only material exposed in the area and extends downward for 200 feet. The hills are subject to slumping and the material is easily eroded by wind and water. The site area is quite stable due to its flat topography. 
Hydrology

The water from the well is derived from the Madison 1 imestone aquifer. The well is a naturally flowing artesian well with a measured flow of approximately $170 \mathrm{gpm}$.

Surface Water

Ponds and lakes are formed easily in the area as there is a high percentage of montmorillonite with pierre shale. In some areas the water leaches salts from the shale, but generally the water is of good quality.

Ground Water

A few shallow wells of low quality from perched water tables are locally available on the Pierre shale. However, most ground water is obtained from the Inyan Kara group which in most cases is abundant in quantity but of lower quality than Madison water.

Water Use

The water in most cases is used for the livestock production but some crop irrigation is being developed.

Ecology

Since the only wildlife known to exist in the area is either widely distributed, unaffected by the project, or prolific reproducers, the project will not significantly alter the site's wildlife. As described above, the soil disturbed by trenching revegetated rapidly as has previously disturbed soil on the project site. No endangered species were affected by the project.

The geothermal water discharged by this project will be the same water which has been used since 1959 for household water, livestock water, 
and reservoir-feed water. Aquatic life in the reservoirs receiving the discharge currently provide excellent habitat for ducks and geese some of which reside year-round on Reservoir 2. During the winter months, the warm geothermal water promotes aquatic life in Reservoir 2 because it prevents widespread freezing. The fish varieties in the reservoir are known to thrive on the warm water provided by the geothermal discharge. 
7. INSTITUTIONAL ISSUES AND PERMITS

\subsection{Private}

Since this project used an existing well with little or no change in either production or discharge practices, no additional governmental permits were required. However, an Environmental Impact Review was submitted. The Environmental Protection Agency office ruled that an Environmental Impact Statement was not required for this project.

The only private consideration which was necessary to resolve involved mineral rights. Since some question existed as to whether the geothermal heat constituted a mineral right, the holders of the mineral rights to the land were asked to furnish a waiver to any such claim. 
8. PRODUCTION DRILLING AND LOGGING

Not Applicable.

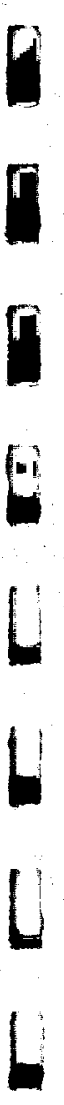




\section{RESOURCE TESTING}

\subsection{Apparatus}

The geothermal resource for this project was the Madison Aquifer. The well used for this project was drilled in 1959 and had an artesian flow of $173 \mathrm{gpm}$ at $153^{\circ} \mathrm{F}$. No reservoir studies or assessment was conducted as a part of this investigation. However, a comprehensive review of the Madison was completed under a previous geothermal investigationl. The only site specific analysis performed at the Diamond Ring Ranch involved corrosion analysis.

Previously analyzed and compiled data on the Madison shows water quality varies widely within the Madison Aquifer. It can generally be said that the water quality is best close to the Black Hills perimeter and decreases radially outward, with the lowest quality occurring to the north of the Black Hills. The northernmost counties in South Dakota have the worst quality, at the greatest depths and some of the highest temperatures, but have the lowest population. This water in most cases exceeds recommended EPA levels for human consumption on several parameters; however, people have been known to drink it with few $i l l$ effects, notably in Midland and Edgemont.

The Madison waters observed, when permitted to cool and evaporate in the atmosphere, will produce a heavy white deposit composed primarily of gypsum and amorphous silica. However, this deposit does not seem to occur in the transmitting pipelines. Madison water is far superior to most water from the shallower Inyan Kara group and is highly prized by the ranchers.

The gas contained within the water is composed largely of nitrogen, carbon dioxide, traces of oxygen, and hydrogen sulfide. The sulfide concentration has been determined on-site by the methylene blue colorimetric method and measured spectrophotometrically. The hydrogen sulfide is apparently the cause of much corrosion. 
There are no dangerous levels of any toxic elements in the Madison water. This permits the water to be used for irrigation in arable solls and as livestock water. Secondary utilization and disposal of cooled Madison Aquifer water does not present any major problems.

\subsection{Tests Conducted}

Because of the complexity of Madison waters and the difficulties encountered in using scaling indices to predict corrosion and scaling tendencies, an experimental program was undertaken under a previous grant ${ }^{1}$ and continued under this project to provide reliable information on 1) the corrosion behavior of commonly used heat exchanger metals and alloys and 2) the probability of scaling. Both of these goals were achieved with the corrosion test rack shown in Figure 4. The test rack had 2-in.-dia samples of the following thirteen materials:

\begin{tabular}{ll} 
Carbon Steel & 1020 \\
\hline Stainless Steel & 304 \\
\hline Stainless Steel & 316 \\
\hline Monel & 400 \\
\hline Admiralty Brass & 443 \\
Copper & 801 \\
Copper Alloy & 715 \\
Copper Alloy & 958 (weld rod) \\
Copper Alloy 2 & 613 \\
Copper Alloy & 614 (weld rod) \\
Aluminum* & 3003 \\
Glass, Plate* & \\
\hline
\end{tabular}

$1_{\text {Ampcoloy }} 483^{R}$

2 Ampco $8^{R}$.

* Not shown

The test rack was placed inside a 4-in. diameter PVC enclosure through which Madison water flowed. Periodic observation of the disks per- 


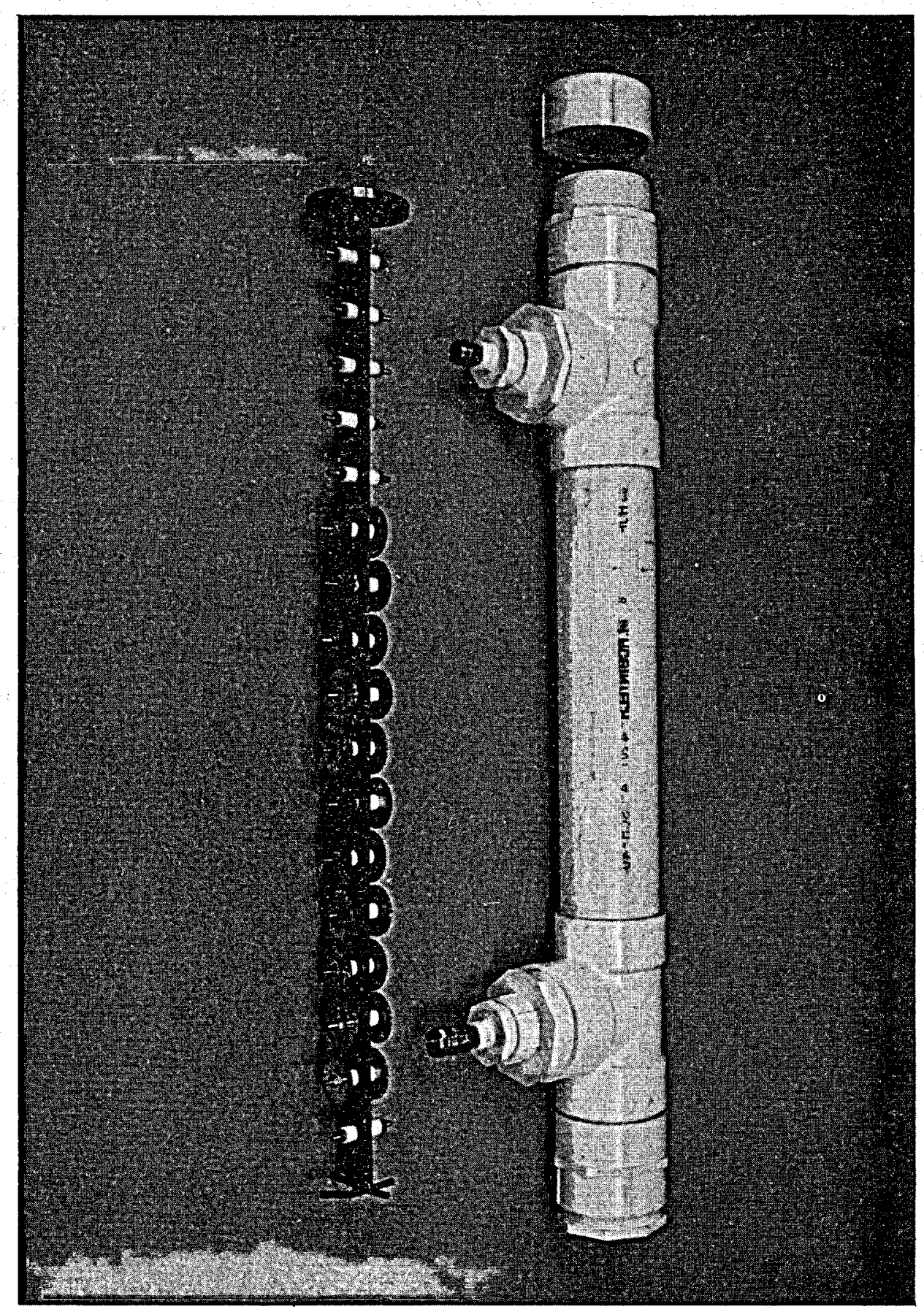

Figure 4 - Corrosion Test Rack 
mitted evaluation of the corrosion and scaling properties of the Madison water. The glass disks were used as a sensitive means of visually assessing the occurrence of scaling. Test racks were installed at the Diamond Ring Ranch, Phllip, South Dakota, and Edgemont, South Dakota, because these locations provided waters of widely different temperatures and chloride and sulfate concentrations. The results of these tests are summarized in Table 1.

The corrosion test rack was installed at the ranch on August 16, 1977. Inspection of the specimens after three weeks' exposure showed the familiar black copper sulfide deposit throughout the assembly. Aluminum 3003 was corroded with large deposits of a white amorphous material covering severe pits. Carbon steel was also severely etched. This rapid attack of aluminum and carbon steel was attributed to high chloride concentrations. Disks of 304 and 316 stainless steel appeared least affected by exposure. 
TABLE 1 - WEIGHT LOSS RESULTS FOR THE COUPON TESTS CORROSION RATE IN $\mu \mathrm{m} / \mathrm{yr}$

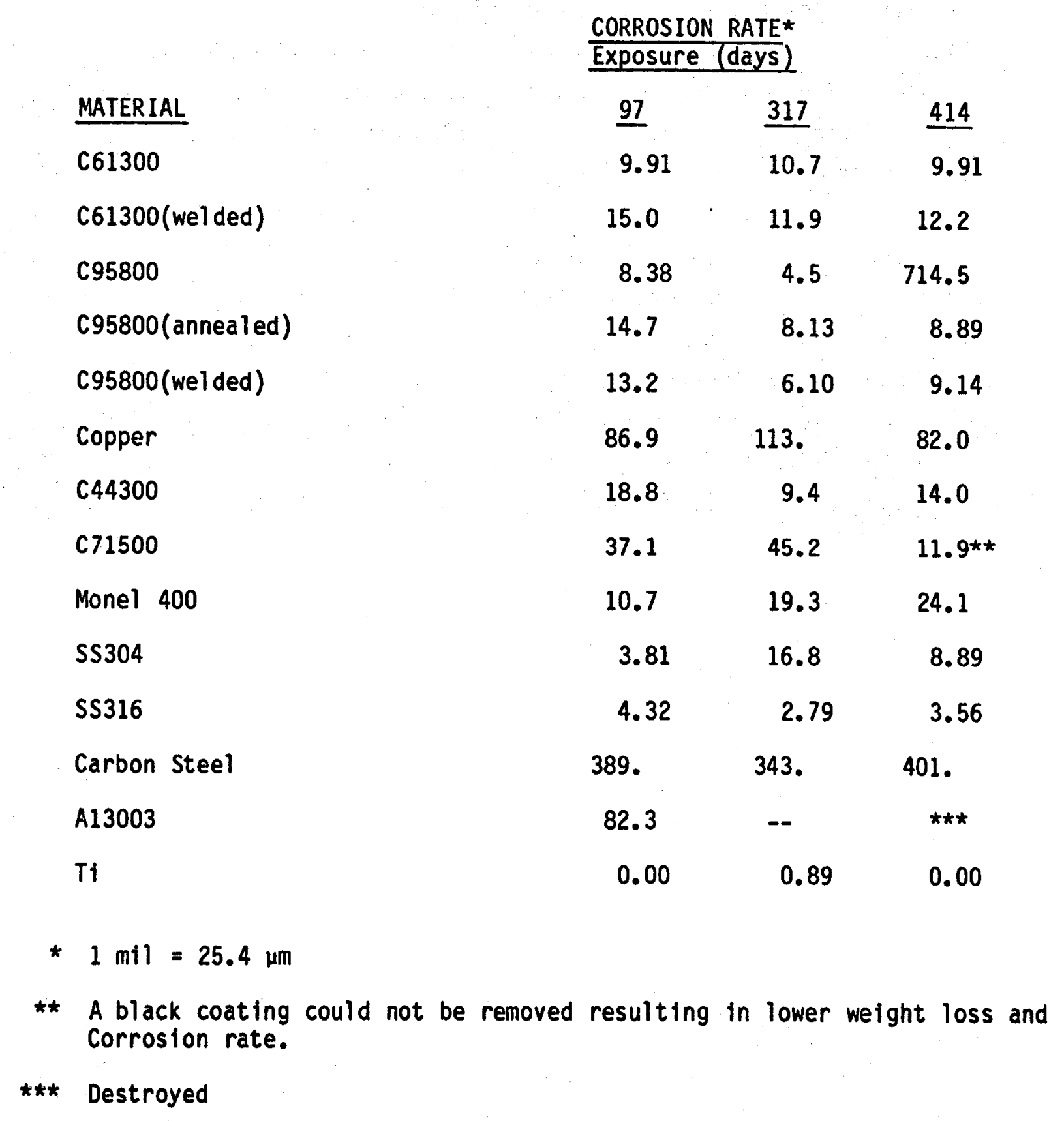


10. DISPOSAL DRILLING AND LOGGING

Not applicable

11. DISPOSAL TESTING

Not applicable

6

$U$

31 


\section{APPLICATION ANALYSIS}

\subsection{Technical}

The user of the geothermal energy under this project was the Diamond Ring Ranch. However, prospective users of such developments are the hundreds of farmers and ranchers in the Madison Aquifer region. Since many of these concerns have inadequate water supplies, the cost of wells to the Madison can often be assigned solely to the development of a water supply. The high demand for rural water is exemplified by such recent projects as a county-wide water distribution system in Mellette County, South Dakota. Wells which might supply such distribution systems could provide tremendous geothermal heating if located within several thousand feet of farm or ranch structures. Little or no geothermal benefit is possible beyond several miles because of thermal losses during distribution and transmission line costs. Wells located near communities could provide space heating similar to that proposed in this project. Such communities could also use the available geothermal heat for grain drying in large grain bins during summer and fall.

The peak energy demand for geothermal space heating on the Diamond Ring Ranch was estimated as follows:

2 large homes and 2 mobile homes

Shop

$$
\begin{aligned}
& 0.3 \times 10^{6} \mathrm{BTU}^{\prime} \mathrm{s} / \mathrm{hr} \text {. } \\
& 0.2 \times 10^{6}
\end{aligned}
$$

Insulated hospital barn

TOTAL

$\frac{0.5 \times 10^{6}}{1.0 \times 10^{6} \text { BTU's/hr. }^{\circ}}$

During the grain drying season, approximately $14 \times 10^{6}$ BTU's are required to dry each 1,000 bushels of grain. Annual harvest may be as high as 200,000 bushels, which translates to an annual grain drying demand of $2.8 \times 10^{9}$ BTU's.

The Madison well discharges $153^{\circ} \mathrm{F}$ water at $173 \mathrm{GPM}$. If heat is extracted from this water by cooling it to $120^{\circ} \mathrm{F}$, a heating capacity of $3.36 \times 10^{6}$ BTU/hr is avallable. Assuming 5 percent transmission 
loss, adequate heat is provided by the existing well to meet peak demand. Grain drying (which would be completed before the onset of peak heating loads) requirements could be met in approximately 34 days of complete use of the geothermal resource while cooling of the water to $120^{\circ} \mathrm{F}$.

Heat for warm stock water was provided by the $120^{\circ} \mathrm{F}$ water discharged after heat extraction for the above cited needs.

\subsection{Economic}

The energy cost for the installation and operation of the system was insignificant compared to the energy derived from the system. Energy consumed by the project was in the form of fuel for trenching, fuel used in travel, energy required in the production of the materials used in the project, and electrical energy required for geothermal fluid circulation and fan coil operation. In total, these energies were estimated to be less than $10^{9}$ BTU's. Assuming a 25 year service life of the facility, and an average energy consumption of 30 percent of the peak rate, yields a total project energy production of $2 \times 10^{12}$ BTU's. Therefore, the energy cost of the project was estimated at only 0.05 percent of the energy production.

Benefits from the proposed geothermal application were assigned the following dollar value at the beginning of the project:

(1) Home heating

$\$ 3,150 /$ year

(2) Shop heating

$2,100 /$ year

(3) Grain drying

$10,000 /$ year

(4) Hospital barn heating $\frac{5,250 / \text { year }}{2}$

TOTAL

$\$ 18,500 /$ year

These costs were obtained from the cost of the alternatives to geothermal heating.

The above cited benefits from space heating are based on energy costs of the projects beginning in 1978. Increases in fuel costs increased 
the above benefits.

The rate of return on investment for the project were calculated from the total project capital cost, the estimated annual operating cost, and the annual benefit. The annual operating cost was estimated to be $\$ 1,000$, the equivalent annual rate of return is 8 percent per annum assuming a 25-year service 1ife. At the end of the project the capital cost was estimated as the consultant's cost for design (\$31K) plus the construction cost $(\$ 156 \mathrm{~K})$. If the cost of the well (\$90K) was included in the cost, the equivalent annual rate of return on investment was 4 percent. 
13. OBTAINING USER COMMITMENT.

The site owner and potential user was selected by the project manager for potential participation in the Direct Utilization of Geothermal Energy program since the Diamond Ring Ranch had one of few geothermal wells suitable for this program. The Ranch owner and operator was very receptive to participation in the program. The involvement of limited parties in this project substantially reduced the complexity of contractual arrangements as compared to distinct heating projects involving large numbers of users. The escape clauses in this project were limited to those provided for in the contract with U.S. Department of Energy. 
14. SYSTEM LOADS

14.1 Peak

The peak heating loads for each application are given below. These loads are the maximum load as determined by calculation and from the size of existing heating systems. The geothermal system was designed to meet these peak loads

\begin{tabular}{lc} 
Grain Dryer & $1,500,000 \mathrm{BTU} / \mathrm{hr}$ \\
Owner's Home & 180,000 \\
Employee's Home & 100,000 \\
Mobile Home 1 & 80,000 \\
Mobile Home 2 & 80,000 \\
Hospital Barn & 110,000 \\
Shop & 210,000 \\
\hline Total Peak Load & $2,260,000$ BTU/hr
\end{tabular}

14.2 Annual

The annual heating loads for this project are highly dependent upon the usage of the grain dryer. For the purpose of this analysis, an average use of 2.5 months per year was assumed. This is very close to actual requirements for grain drying at the Diamond Ring Ranch.

The annual load factor for space heating in South Dakota is $30 \%$. Applying this to the space heating peak loads gives the following annual load requirements.

ANNUAL HEATING LOAD REQUIREMENTS

$\begin{array}{ll}\text { Space Heating } & 2.00 \times 10^{9} \text { BTU } \\ \text { Grain Drying } & \frac{2.74 \times 10^{9}}{4.74 \times 10^{9} \text { BTU }} \\ \text { Total } & \end{array}$

\subsection{Load Factor}

As indicated above, the space heating load factor of used was $30 \%$ while a 2.5 month duty is equivilent to a $20.8 \%$ load factor for the grain dryer. 


\subsection{Fuel Replaced}

The efficiency for propane heating was $80 \%$. This same factor was used for the grain dryer since the air for drying contains no combustion moisture. The overall production efficiency for electricity is $33 \%$. That is, for each BTU of fossil fuel consumed, 0.33 BTU of heat energy is delivered to the space for heating. Since resistance heating at the point of delivery is $100 \%$ efficient the only losses with electric heat are in its generation and distribution.

. The fuel replaced by the geothermal system is related to the type of heating replaced. In the table below, the amount of fossil fuel replace is shown for each application.

Application

Owner's Home

Employee's Home

Mobile Home 1

Mobile Home 2

Hospital Barn

Shop

Grain Dryer

TOTAL

$\frac{\text { Fuel Replaced }}{\text { Electric }}$

Propane

Propane

Propane

011 and Electric

Propane

Propane
Replaced (BTU/yr)

$1.18 \times 10^{9}$

$.33 \quad 1$

.26 "

$.26 \quad 11$

$.36 \quad "$

1.15 "

$\frac{4.5011}{8.04 \times 10^{9}}$

This quantity of fossil fuel is equivalent to 1436 barrels of oil per year. 
15. PRODUCTION SYSTEM DESIGN

The existing well was completed in 1959. The well depth was 4112 feet and had 8-in. casing at the surface. The method of completion was open hole. No logging or modification of the well was included as part of this project. 


\subsection{Selection Process}

Since the geothermal well used for this project was drilled in 1959 primarily for irrigation and stock watering the logical choice for a disposal system was to simply continue to discharge the geothermal water into open reservoirs constructed for stock watering and irrigation supply. This disposal process would constitute little if any change in prevailing practice at the Diamond Ring Ranch. This disposal plan was approved by the U.S. Environmental Protection Agency.

\subsection{Design}

The disposal system design consisted of simply allowing the spent geothermal water to flow through a gate valve into an open channel to the disposal reservoir. The discharge water from the grain dryer flowed to a west slope reservoir approximately 1 mile west of the Diamond Ring Ranch structures. The discharge water from the space heating system flowed to the reservoir near the owner's home through an open channel. Approximately $25 \%$ of the geothermal water exiting the space heating system was pumped directly to stock watering tanks in the cattle feedlot where it was consumed by approximately 4,000 head of cattle. A negligible amount of the water was used, as in the past, for domestic use. 
17. TRANSMISSION AND DISTRIBUTION SYSTEM DESIGN

\subsection{Selection Process}

Since the geothermal well drilled in 1959 was at a higher elevation than the geothermal applications and flowed artesian no pumping equipment was required at the well site.

\subsection{Design}

Previous studies of the geothermal water exiting the well indicated significant quantities of gas exiting the water. Therefore a degasser was deemed necessary at the wellhead. Scaling in previous lines from the well was not observed. However, a small amount of iron pyrite sediment was found to collect in low points of previously constructed lines. The accumulation of this deposit required periodic cleaning of the lines. Consequently, in the geothermal system, all low points in the line were designated to have flushing cleanouts.

One of the major concerns during the design phase was the extent of heat loss from the 4000-foot long transmission line. The thermal conductivity of the soil at the project site is of great importance in the prediction of these heat lossses. The thermal conductivity was measured on December 5, 1978 by the following procedure.

The rate of heat loss, dQ, from a buried pipe of length $\mathrm{dL}$ is given by

$$
\frac{d Q}{d L}=\operatorname{Ln}\left[\frac{2 \pi k\left(T-T_{S}\right)}{\frac{2 N}{D}+4\left(\frac{N}{D}\right)^{2}-1}\right]
$$

where 


$$
\begin{aligned}
K & =\text { thermal conductivity } \\
L & =\text { pipe length } \\
T & =\text { water temperature in the pipe } \\
T_{S} & =\text { temperature of the soil at the air surface } \\
N & =\text { depth of the pipe } \\
D & =\text { diameter of the pipe }
\end{aligned}
$$

This expression may be integrated over the length of the pipeline to give

$$
\ln \frac{\left(T_{F}-T_{S}\right)}{\left(T_{i}-T_{S}\right)}=-\frac{2 \pi k L}{\rho C_{p} F \ln \left(2 \frac{N}{D}+4\left(\frac{N}{D}\right)^{2}-1\right)}
$$

where

$$
\begin{aligned}
& T_{F}=\text { final water temperature } \\
& T_{i}=\text { initial water temperature } \\
& p=\text { density of water } \\
& C_{p}=\text { heat capacity of water } \\
& F=\text { flow rate }
\end{aligned}
$$

At the project site, a small duck pond is continuously fed geothermal water during the winter. The pond receives $1.36 \mathrm{gpm}$ through approximately 5000 feet of 1.25 inch line. On December 5,1978 , after several weeks of subfeezing weather, the temperature of the water existing the pipe was $105^{\circ} \mathrm{F}$ while the temperature of the geothermal water entering the pipe was $145^{\circ} \mathrm{F}$. Substitution of these data in the above equation results in a value for the thermal conductivity of

$$
k=0.0397 \frac{\mathrm{BTU}}{\mathrm{hr} \cdot \mathrm{ft} \cdot{ }^{\circ} \mathrm{F}}
$$


In making this calculation, the soil temperature was conservatively estimated as $23^{\circ} \mathrm{F}$ wich was the same as the air temperature. For the transmission line,

$$
\begin{aligned}
L & =3000 \mathrm{ft} \\
N & =6 \mathrm{ft} \\
D & =0.5 \mathrm{ft} \\
F & =173 \mathrm{gpm} \\
T_{i} & =153^{\circ} \mathrm{F}
\end{aligned}
$$

Under the worst possible conditions $\mathrm{T}_{\mathrm{s}}=-20^{\circ} \mathrm{F}$. For these conditions, the temperature of the geothermal water arriving at the isolation exchanger will be $152.6^{\circ} \mathrm{F}$ which is only a $0.4^{\circ} \mathrm{F}$ drop.

For a typical recirculating line,

$$
\begin{aligned}
L & =1500 \mathrm{ft} \\
N & =6 \mathrm{ft} \\
D & =0.25 \mathrm{ft} \\
F & =50 \mathrm{gpm} \\
T_{i} & =130^{\circ} \mathrm{F} \\
T_{S} & =-20^{\circ} \mathrm{F}
\end{aligned}
$$

Under these conditions, $T_{F}=129.5^{\circ} \mathrm{F}$ wich is a $0.5^{\circ} \mathrm{F}$ drop.

These results show that heat losses in transmission lines are insignificant and that no special insulation for the lines need to be provided.

\subsubsection{General Description}

At the wellhead, a six-inch diameter flanged tangential type air separator manufactured by Amtrol Inc. of West Warwick, Rhode Island was installed to remove gases evolving from the geothermal water. The exit from the degasser consisted of six-inch PVC pipe which was buried at a depth of approximately 4 to 5 feet. The distance from the well to the grain dryer was approximately 4,000 feet. Due to the moderately undulating terrain between the wellhead and the grain dryer, two 
low spots in the line were unavoidable. Both of these low spots were fitted with a manhole with a valve and a tee so as to allow periodic flushing of the distribution line. From a point several hundred yards from the grain dryer, the six-inch line branched into two four-inch lines; one running to the grain dryer and the other continuing approximately another 1,000 feet to the shop exchanger. One additional cleanout was required on the section of the line from the tee to the shop. Figure 2 shows the route and layout of the transmission line. 
18. SYSTEM DESIGN

\subsection{Selection Process}

In selecting a pipe size to carry a given volume of water, consideration was given to more than flow rate. The selection of pipe size determines the pump size required to overcome head losses in the geothermal distribution pipeline system. A smaller pipe size generally requires a larger pump which in turn consumes more energy in operation. The smaller pipeline generally requires a smaller initial investment.

A case in point is shown in Figure 5. This Figure was generated before a separate isolation exchanger for the grain dryer had been conceived. In this case either a three- or four-inch pipeline would carry the required volume of 100 gallons per minute to the grain dryer. The initial investment for the four-inch pipeline system including a 2.5 horsepower pump was approximately $\$ 4,500$. The threeinch pipeline system would require an initial investment of approximately $\$ 3,500$ including a 7.0 horsepower pump. The operating cost of the three-inch system was determined to be about $\$ 500$ less per year than the four-inch system. After a period of approximately two years, the cost of the four-inch system was calculated to be less than the three-inch system. Based on this analysis, the four-inch system was selected as more economical.

One of the assumptions used in this analysis was that the larger pump required for the three-inch system would require the full horsepower output of the pump. When the system is installed and all components are new, less than full horsepower is generally required. This will directly affect the annual operating cost. The system was designed to accommodate potential increases in pumping requirements resulting from changes in pipeline roughness. 


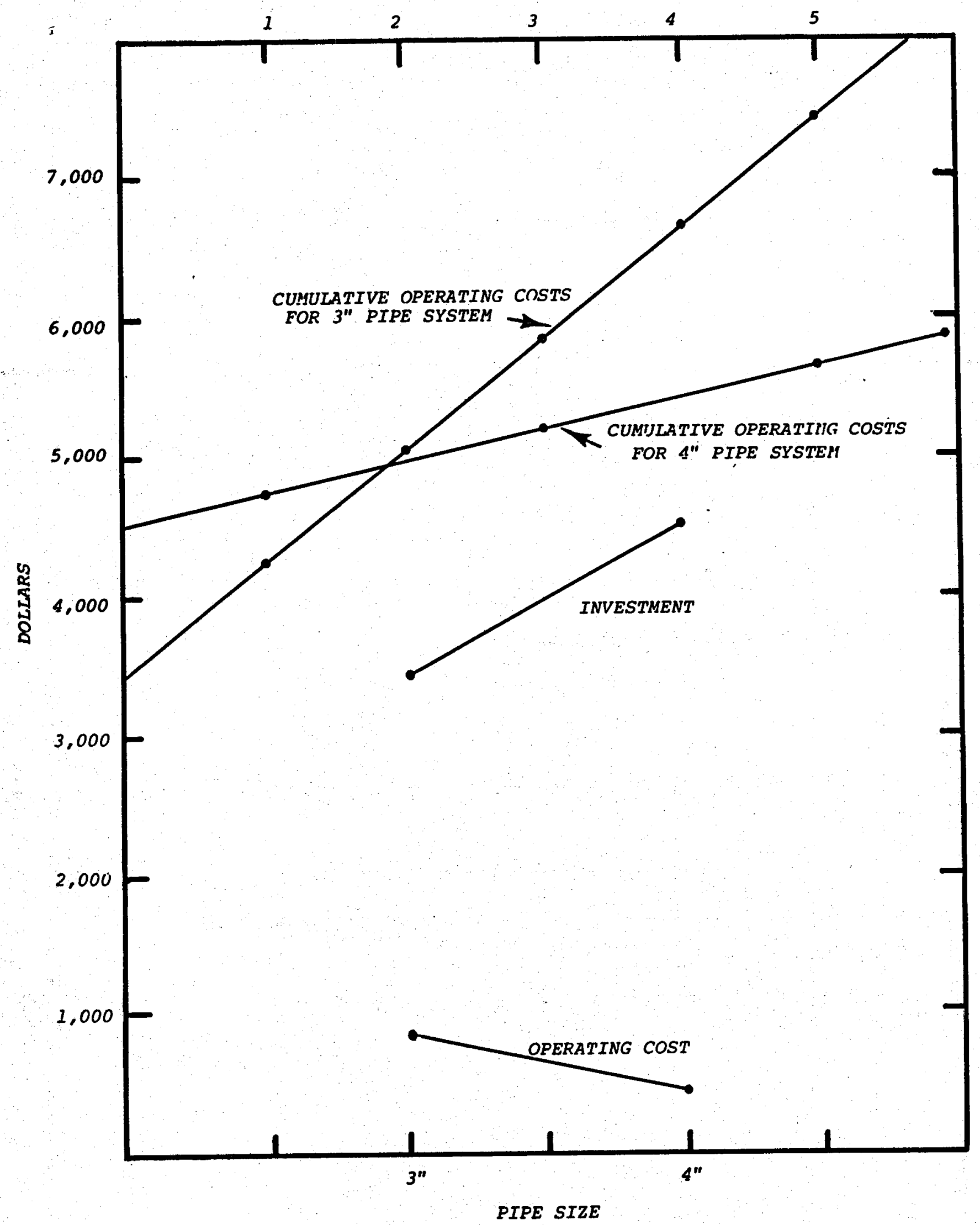

FIGURE 5. GRAIN DRYER PIPELINE SIZE - COST COMPARISON 


\subsection{General Description}

Figure 6 shows the schematic layout of the distribution system. Figure 2 shows the location and route for these recirculating lines.

The transmission system consists of two closed hydronic loops: one supplying the shop, hospital barn, and the two trailer homes and one supplying the owner's home and the employee's home. All of the lines are four-inch PVC pipe buried approximately four feet deep except inside each space heating application where the lines are reduced to one-inch diameter and located above ground. Flow balance to each application is achieved through the use of conventional bronze Circuit Setter valves.

Initially, protection from freezing was provided for by an ancillary electrical generating plant. However, this proved unreliable and passive protection was eventually provided by using a water-ethylene glycol mixture in the recirculating lines.

The distribution system at the grain dryer was very simple owing to the close proximity of the isolation plate exchanger to the water-toair radiators. The short above-ground recirculating lines were filled with a water-propylene glycol mixture at the onset of the project to provide for freezing protection. The geothermal-water side of the isolation exchanger was protected from freezing during off periods by a small hole in the shut-off gate valve feeding geothermal water to the exchanger. This provides a small, constant flow through the exchanger. 


\section{APPLICATION SYSTEM DESIGN}

\subsection{Selection Process}

All of the insulated structures at the project site were selected to be geothermaliy heated. No trade-off studies were performed in regard to which insulated structures were to be heated. As noted in Section 1.3 the feedlot sheds were dropped from the project scope because the cost of heating them was estimated to be approximately $\$ 25,000$ with only marginal benefit the result.

Trade-off analyses were performed in regards to:

1) Direct delivery versus isolated recirculation loop systems,

2) Location of Isolation System Exchangers

The direct delivery system would have supplied raw geothermal water to each application. This would have necessitated corrosion resistant exchangers at each application and a substantially more complicated flow control system. The isolation loop system was selected because it had lower cost, confined all corrosion and scaling problems to central isolation exchangers, and allowed less complicated flow control for each application.

The location of the central, isolation exchanger was always presumed to be at the shop since it was centrally located with respect to all of the applications. However, the cost of recirculating piping and pumping costs to the grain dryer were very high. Therefore, to reduce the construction cost, a second isolation heat exchanger was placed at the grain dryer. This also permitted a smaller supply line from where the grain dryer tap was made to the shop. This arrangement reduced the construction cost by approximately $\$ 10,000$.

19.2 Design

A major design consideration was simplicity since the Diamond Ring Ranch is 50 miles from the nearest city where competent maintenance 
and repair service personnel might be found for sophisticated control systems. A second major objective was to build a system which could withstand prolonged electrical power outages which are common during severe winter storms.

Piping layout

The geothermal well is approximately 4,000 feet from the grain dryer and the structures to be heated. Figure 2 shows the pipeline 1 ayout. A six-inch fiberglass reinforced PVC pipeline with slip joints was placed from the well to the grain dryer. At that point the line branches into two four-inch 1 ines; one runs into the grain dryer building and one to the shop. In the grain dryer, the geothermal water flows through an Alfa-Laval plate-type, water-towater, heat exchanger (Model $P$-31) with 58 plates. The water is then discharged into a ravine and runs to a large stock dam. The flow from the well is gravity fed and is controlled with a pinch valve at the discharge point.

In the shop, the geothermal water flows through the same model heat exchanger used in the grain dryer. The only difference is that the shop exchanger has 54 plates. The discharge from the shop runs to a tee where it can either be discharged into a ravine leading to a collection reservoir or allowed to flow through a looped two-inch PVC line cemented into the floor of a guest house and garage which are adjacent to the owner's home.

A significant amount (up to $25 \mathrm{gpm}$ ) of the raw geothermal water leaving the shop at the heat exchanger is pumped to the livestock watering system from a point several feet downstream from the shop exchanger.

Geothermal path

A water-propylene glycol mixture is circulated by pump throughout the plate type heat exchanger at the grain dryer and a large water to air 
radiator. Air is drawn through the radiator by a tractor driven fan in the grain dryer. The water glycol mixture is used so as to prevent freezing in the geothermal system during the winter. Propylene glycol was used because it is nontoxic thereby preventing any contamination of feed supplies.

At the shop a water-ethylene glycol mixture is circulated through the plate type exchanger and through two heating loops. One loop runs to the hospital barn, the mobile homes and the shop. The second loop runs to the employee's home and the owner's home. Heat from the recirculated mixture is used to heat air in all the structures. In the hospital barn and shop, fan coil units are used. In the homes water to air exchangers were placed in existing plenums of the forced air heating systems. The preexisting heating systems in the homes were left intact for backup heating.

\section{Unique features}

The corrosiveness of the geothermal water requires the use of stainless steel 316 for all exchanger services in contact with the geothermal water. Consideration was given to the direct use of geothermal water in water to air exchangers but the cost of such units and associated control problems made that approach unacceptable in all cases except at the grain dryer where the cost was comparable to the design finally accepted. At the grain dryer, a direct geothermal to air approach had obvious advantages with respect to freezing protection but was rejected because of the eventual prospect of corrosion fallure resulting in very costly water damage to grain in the dryer. Also, the time required to replace failed coils could result in the loss of undried grain.

\subsubsection{Controls}

The electric control system for the pumps was centralized in the pumpheat exchanger room in the shop. This minimized the electrical modification to the homes, shop and hospital barn. It also facilitated 
manual control of the pump when setting the flow rates and also in emergencies when the pumps must be cross linked. Installation and service was also made easier.

Figure 7 shows the control concept for the homes. Thermostat No. 1 is the exclusive thermostat control for the furnace or heat pump. This is set at a slightly lower temperature than thermostat No. 3 which controls both the forced air circulating fan and the geothermal hydronics heating pump. Thermostat No. 2 monitors the water temperature in the pipe. Thus, if the water temperature drops past a preset limit, the pump is switched on and the response time is minimized when the home needs heat. The shop and hospital barns did not need to be linked into existing systems.

Figure 8 shows the underground control line layout. These control lines operate the pump motors when geothermal heating is needed. These lines were buried in the same trenches as the pipes.

The electrical modifications for the employee's home, mobil homes and owner's home are shown in Figures 9 and 10 . The relay designation Rl, R2, etc., thermostat designator $T 1, T 2$, etc., and pump motor relay, breaker, P1, P2, etc., are consistent throughout this report. New electrical controls were indicated by the notation, "(add)". The power system and control diagrams for the hospital barn and shop are shown in Figure 11. Modifications to the Behlen Model 380 continuous grain dryer are shown in Figure 12. These controls assure that there will be enough heat for the homes plus protection of the heat exchangers from freezing. Figure 13 shows the composite pump control system with all relays, thermostats and pump motor controllers. The three way hand-off-auto switches allow manual control for the pumps. All of these controls are centralized into a distribution center in the shop.

\subsubsection{Major Components}

Major components consisted of the plate type heat exchangers at the 


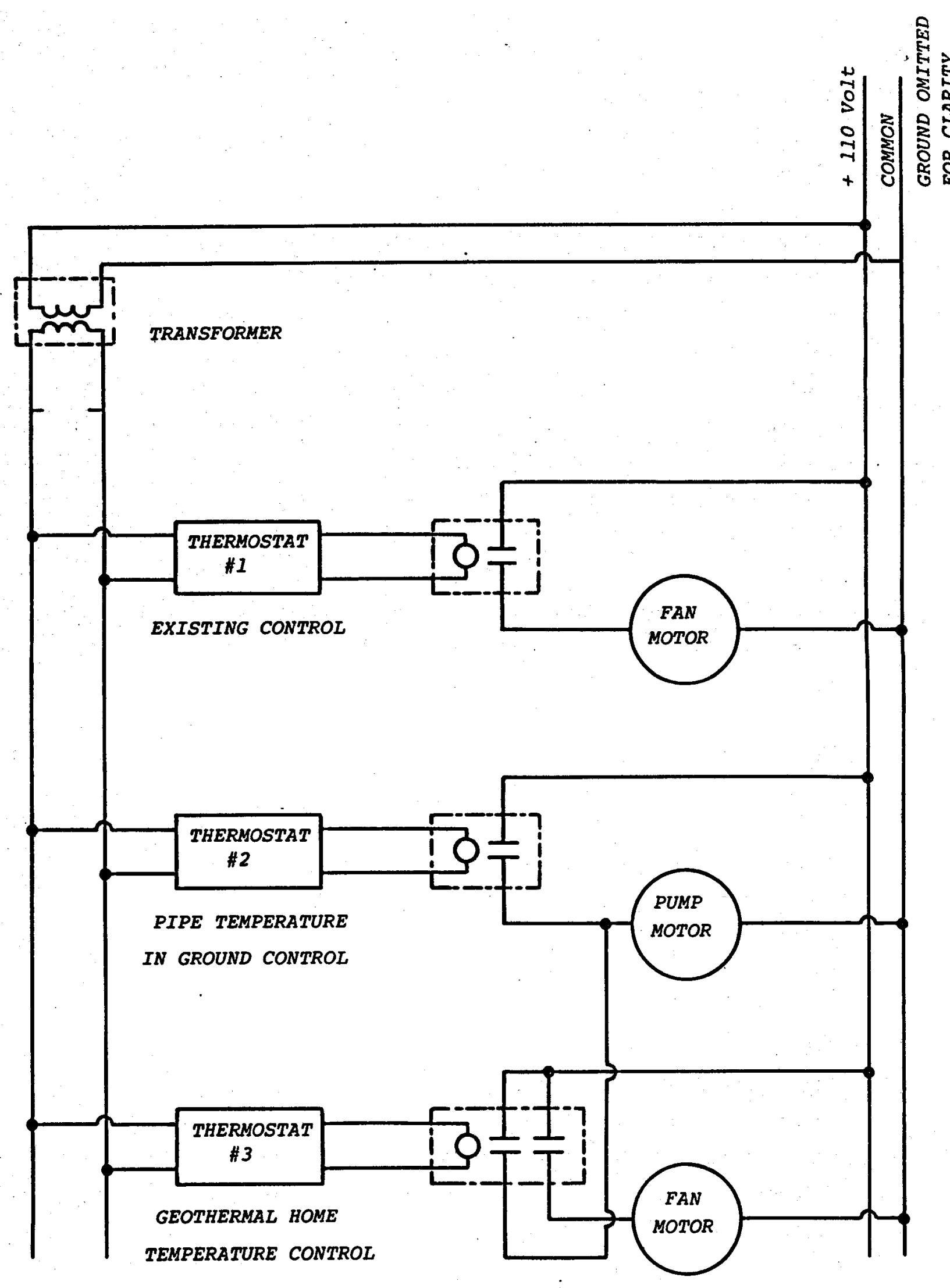

FIGURE 7. TYPICAL HEATING/GEOTHERMAL PUMP ELECTRICAL CONTROL. 



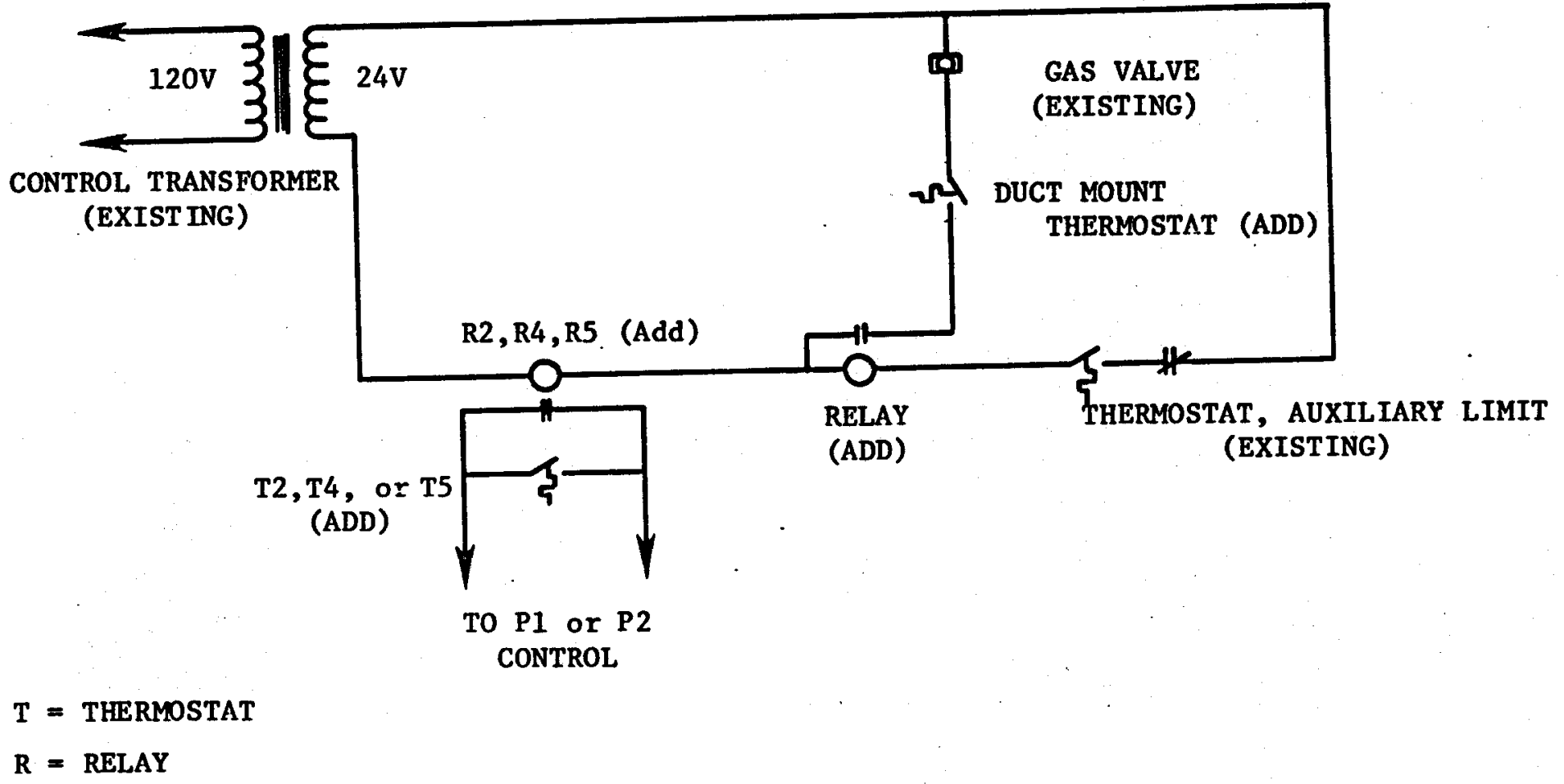

Figure 9. Furnace and Geothermal Heat Controls for the Employees Home and Mobile Homes No. 1 and 2 . 



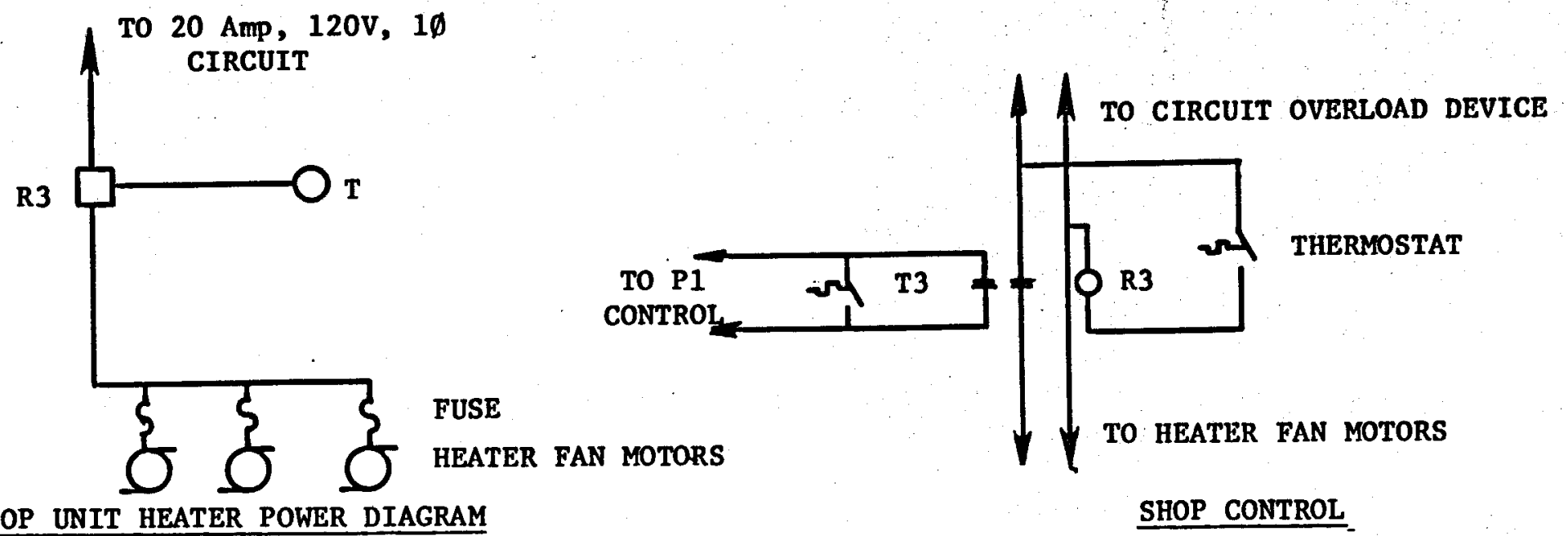

SHOP UNIT HEATER POWER DIAGRAM

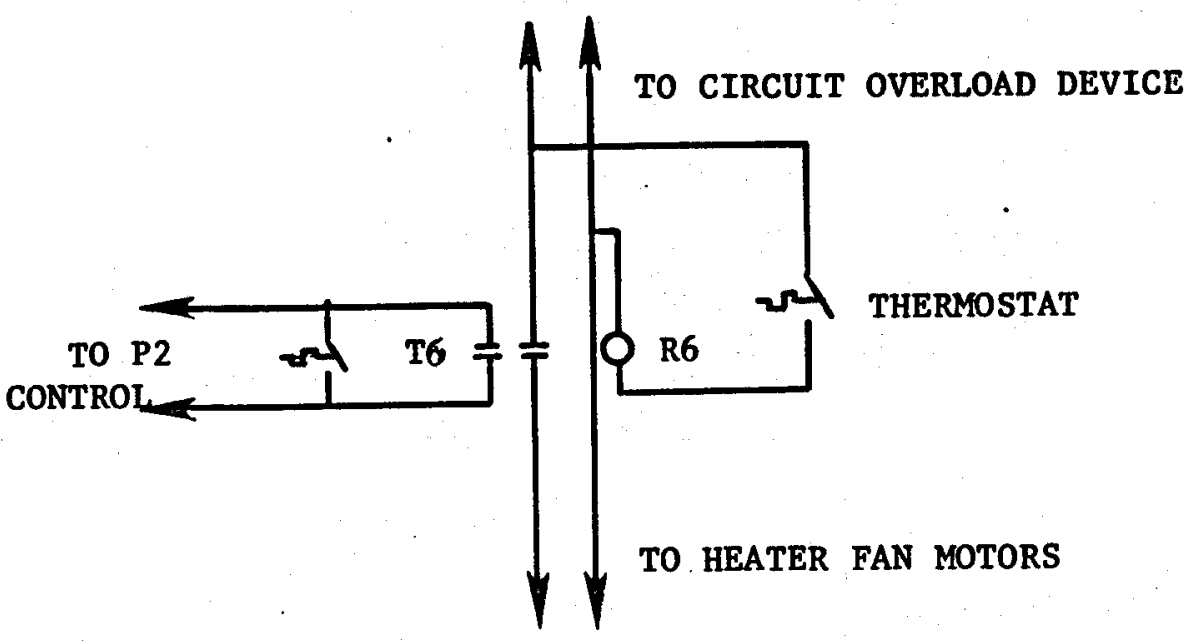

HOSPITAL BARN CONTROL DIA'GRAM

HOSPITAL BARN UNIT HEATER

POWER DIAGRAM

Figure 11. Hospital Barn and Shop Unit Heater Power and Control Diagrams. 



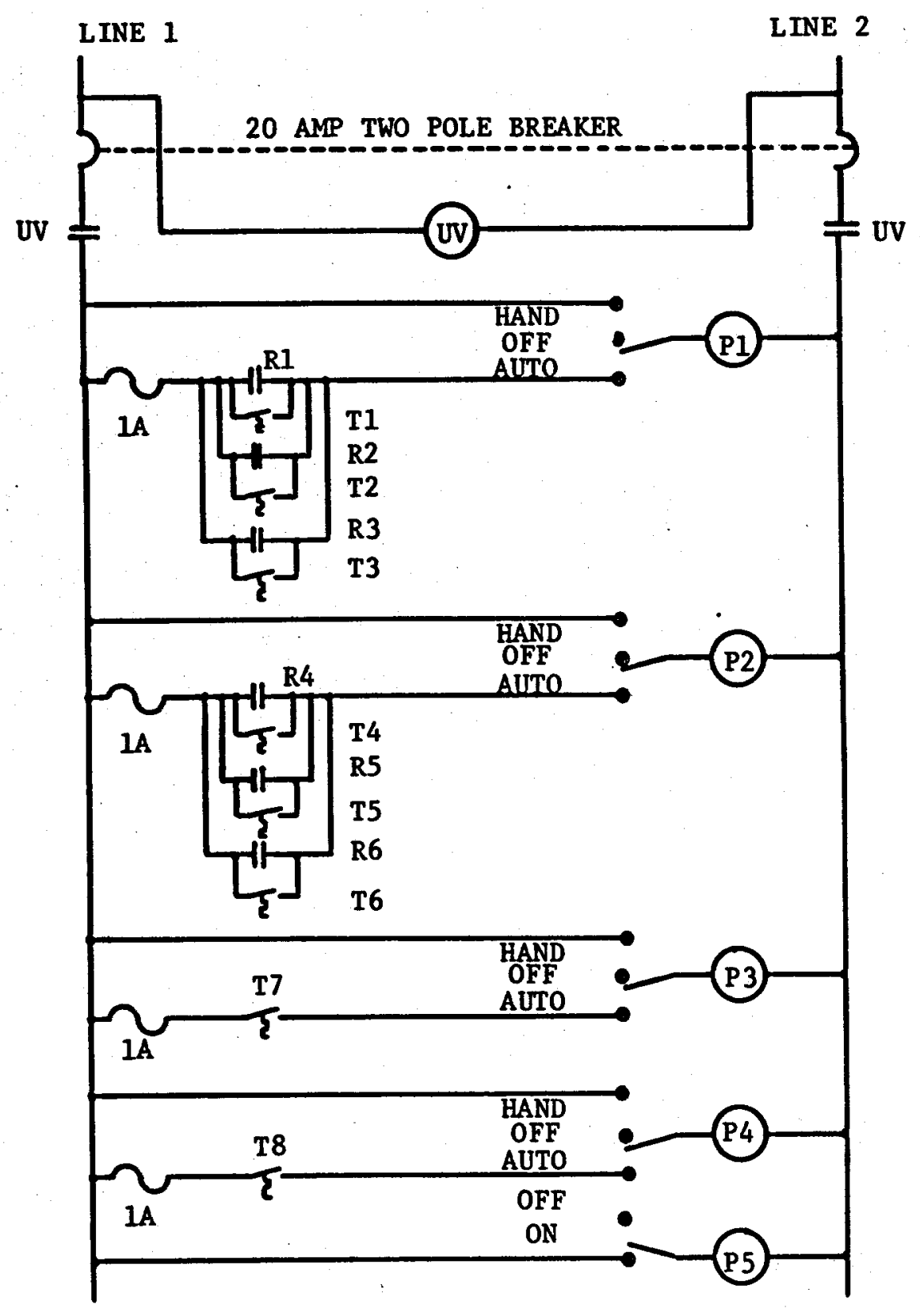

Figure 13. Pump Control Diagram 230 Volt (New Service). 
grain dryer and in the shop, recirculation pumps, fan coil units, and radiators. The manufacturer and description of each of these units is shown below.

Table 2 - Major Components

\begin{tabular}{|c|c|c|}
\hline Equipment & Manufacturer & $\frac{\text { Part Number }}{\text { (quantity) }}$ \\
\hline Grain Dryer Exchanger & $\begin{array}{l}\text { Alfa-Laval Thermal } \\
\text { Somerville, NJ }\end{array}$ & $\begin{array}{l}\text { P31-SA } \\
\text { (58 plates) } \\
\text { (one) }\end{array}$ \\
\hline Shop Exchanger & $\begin{array}{l}\text { Alfa-Laval Thermal } \\
\text { Somerville, NJ }\end{array}$ & $\begin{array}{l}\text { P31-SA } \\
\text { (52 plates) } \\
\text { (one) }\end{array}$ \\
\hline Grain Dryer Pump & $\begin{array}{l}\text { Bell and Gossett } \\
\text { Morton Grove, IL }\end{array}$ & $\begin{array}{l}\text { Series } 1513 \text { Type B } \\
11 / 2 \text { HP } 1750 \text { RPM } \\
61 / 2 " \text { Impeller } \\
\text { (one) }\end{array}$ \\
\hline Shop Pumps & $\begin{array}{l}\text { Bell and Gossett } \\
\text { Morton Grove, IL }\end{array}$ & $\begin{array}{l}\text { Series } 1531 \text { Type B } \\
11 / 2 \text { HP } 1250 \text { RPM } \\
7^{\prime \prime} \text { Impeller } \\
\text { (two) }\end{array}$ \\
\hline $\begin{array}{c}\text { Hospital Barn } \\
\text { Fan Coils }\end{array}$ & $\begin{array}{l}\text { Trane Company } \\
\text { LaCross, WI }\end{array}$ & $\begin{array}{l}\text { Model 146P } \\
\text { (three) } \\
\text { Model 42W2 } \\
\text { (one) }\end{array}$ \\
\hline Shop Fan Coils & $\begin{array}{l}\text { Trane Company } \\
\text { LaCross, WI }\end{array}$ & $\begin{array}{l}\text { Model 60W2 } \\
\text { (one) } \\
\text { Model 202PL } \\
\text { (two) }\end{array}$ \\
\hline Grain Dryer Radiators & $\begin{array}{l}\text { Trane Company } \\
\text { LaCross, WI }\end{array}$ & $\begin{array}{l}\text { Type W coil } \\
30 \times 80-i n .4 \text { row } \\
\text { (three) }\end{array}$ \\
\hline Mobile Home Radiators & $\begin{array}{l}\text { Trane Company } \\
\text { LaCross, WI }\end{array}$ & $\begin{array}{l}\text { Type P4 coil } \\
12 \times 36-\text { in. } 4 \text { row } \\
\text { (two) }\end{array}$ \\
\hline Owner's Home Radiator & $\begin{array}{l}\text { Trane Company } \\
\text { LaCross, WI }\end{array}$ & $\begin{array}{l}\text { Type P4 Coil } \\
24 \times 36-\text { in. } 4 \text { row } \\
\text { (one) }\end{array}$ \\
\hline Employer's Home Radiator & $\begin{array}{l}\text { Trane Company } \\
\text { LaCross, WI }\end{array}$ & $\begin{array}{l}\text { Type P4 Coil } \\
18 \times 24-i n \cdot 4 \text { row } \\
\text { (one) }\end{array}$ \\
\hline
\end{tabular}




\subsubsection{Energy Monitoring System}

Energy delivered by the geothermal system was monitored using BTU meters located at the hospital barn, the shop, the two mobile homes, the employee's home and the owner's home. The BTU meters selected were Model RS805 Rho Sigma meters manufactured in North Hollywood, California. These units consisted of a flow meter, two temperature sensors and a solid state integration unit.

Energy monitoring at the grain dryer consisted of measuring the increase in air temperature through the grain dryer. This information combined with the volumetric flow rate of air through the dryer allowed the calculation of energy delivered by the geothermal system.

\subsubsection{Evironmental Control and Monitoring}

The only environmental monitoring required for this project involved the periodic sampling of reservoirs receiving the discharge water from the geothermal system. As shown in Figure 2 the discharge from the geothermal system ran to Reservoir 1 which flowed into Reservoir 2 and ultimately into a Reservoir 3 approximately six miles downstream. Water samples were drawn from these reservoirs on a periodic basis before and after geothermal system operation. The results of the water monitoring study are presented in a later section. 
20. PRODUCTION SYSTEM CONSTRUCTION

Not applicable; used an existing well.

21.-24. DISPOSAL, TRANSMISSION, DISTRIBUTION, AND APPLICATION SYSTEM CONSTRUCTION

The entire geothermal system was built under one contract awarded to Gerlack and Ebert of Rapid City, South Dakota.

\section{1.-24.1 Bidding, Selection and Contract}

The bid document for construction was prepared by RE/SPEC, Inc., a project participant. A complete copy of this bid document is contained in the Fourth Quarterly Report for the project submitted July 19, 1979. Two firms submitted bids on May 14, 1979 for the construction phase of the project.

Oahe Plumbing and Heating; Pierre, South Dakota $\$ 204,979$.

Gerlach and Ebert Plumbing; Rapid City, South Dakota $\$ 245,000$.

Since both of these bids far exceeded the construction phase budget, the original design was modified to reduce costs and negotiated bids were received. Significant changes were:

1. Replacement of the feedlot heat exchanger with concrete slab heating demonstrating the same technology.

2. Splitting of the isolation heat exchanger with one part at the grain dryer and one part at the shop.

3. Reduction of the pipeline minimum depth from 5 to 4 feet.

4. Reduction in the size of the control wire from \#8-2 to \#10-2.

5. Simplification of the grain dryer heat exchanger building.

6. Redesign of the mobile home heating system from below to above ground.

Gerlach \& Ebert Plumbing submitted a new bid for the revised design of $\$ 154,589.00$. Oahe Plumbing \& Heating did not submit a revised bid or provide relevant supporting documents as requested apparently because 
of the turmoll caused by the death of the firm's owner. Therefore, the bid of Gerlach \& Ebert Plumbing was accepted. The complete contract with design drawings is contained in the fourth quarterly report submitted for this project on July 19, 1979.

Construction began July 23, 1979 and the construction contract required a 125 day completion.

\section{1.-24.2 As-Built System}

The system was constructed in accordance with the design prepared by RE/SPEC Inc. There were no significant changes made in the plans during the construction phase. However, $\$ 500$ of the contract was withheld from the contractor to cover the cost of electrical hookups made to the grain dryer which the contractor chose not to complete. 
25. SYSTEM MANAGEMENT AND ORGANIZATION

\title{
25.1 Organizations and Participants
}

\author{
Participants for this geothermal project were as follows: \\ South Dakota School of Mines and Technology \\ Rapid City, South Dakota \\ RE/SPEC, Inc. \\ Rapid City, South Dakota \\ Diamond Ring Ranch \\ Midland, South Dakota \\ Gerlach \& Ebert Plumbing \\ Rapid City, South Dakota
}

Figure 14 is an organization chart for the project.

\subsection{Responsibilities}

The project director coordinated the activities of RE/SPEC Inc. and the Diamond Ring Ranch management. The project director with assistance from the assistant director, Dr. Carda, provided RE/SPEC Inc. with the corrosion water chemistry and well data required to arrive at a preliminary design. This preliminary design was submitted to the Diamond Ring Ranch management for non-technical revision as required. After agreement by both RE/SPEC Inc. and Diamond Ring Ranch was obtained, final design for the project was completed and submitted to the project director for final approval. Bids were obtained by RE/SPEC Inc. for the project and upon review by the project director were awarded to Gerlach \& Ebert Plumbing of Rapid City, South Dakota. They worked directly under the supervision of RE/SPEC Inc. All supervision of construction was performed by RE/SPEC Inc. who recommended to the project director payment for work completed. After the construction phase was completed, RE/SPEC Inc. prepared an operation 


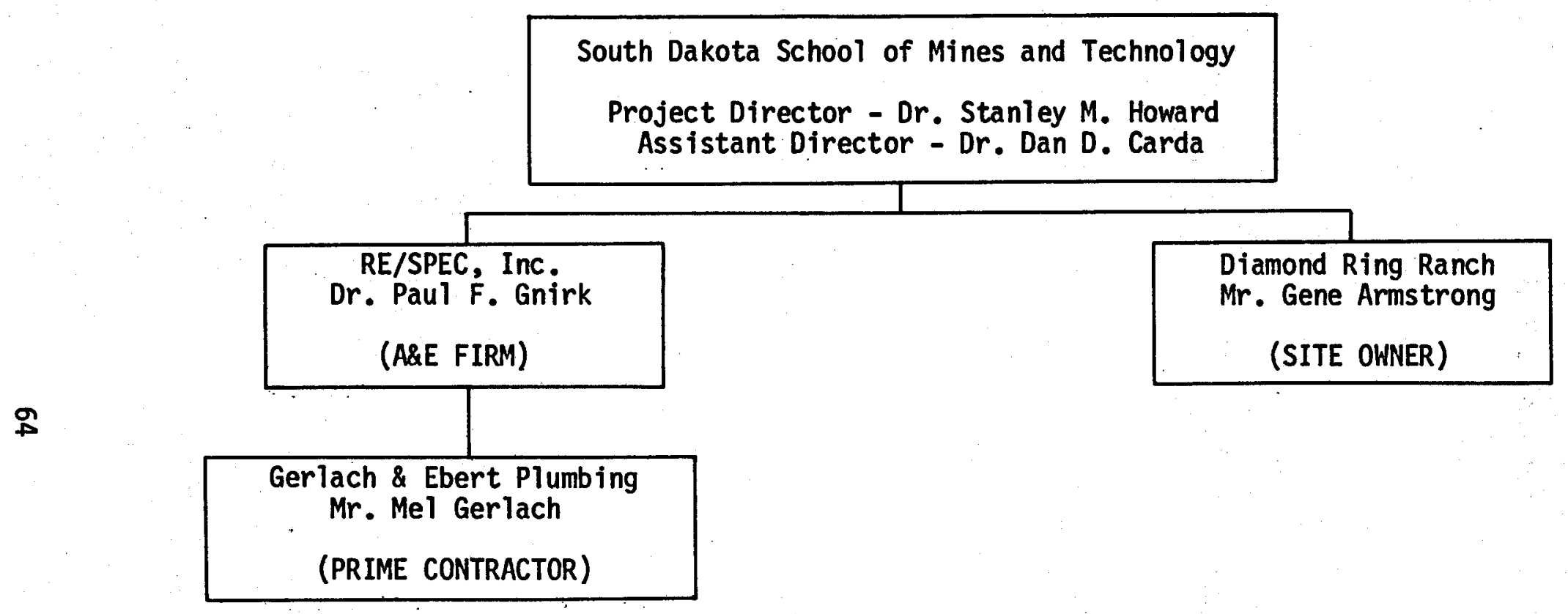

Figure 14 - Management Chart 
manual for the systen which was presented to the Diamond Ring Ranch management. The operation and monitoring team consisted of the South Dakota School of Mines and Technology and the Diamond Ring Ranch. The Diamond Ring Ranch was primarily responsible for operation of the system while the South Dakota School of Mines personnel were responsible for the monitoring of the system and technical assistance. 


\section{PRODUCTION SYSTEM PERFORMANCE}

The geothermal well continued to flow as expected after being fitted with a degasser connected to the geothermal transmission line. The only problem arising after the construction was completed was a leak near the casing as it exited at the ground. This leak continued to worsen from construction completion in late 1979 to project completion in 1982. At the end of 1982, the leak had increased to approximately 50 gallons per minute. Diamond Ring Ranch management had determined it necessary to repair the casing which was the cause of the leak. This was completed in late 1982 by exterior cementing.

\subsection{Post Construction Modification}

Shortly after the degasser was placed in operation at the wellhead, an air lift problem in the degasser vent became apparent. Several gallons of water per minute were being air lifted through the vent, falling on the ground and creating a mess. This problem was rectified during the operation phase by the project director and his personnel by installing a three-inch diameter PVC pipe approximately 20 feet long vertically from the degasser. This diameter was large enough to disrupt air lift of the water from the degasser. After this modification no additional loss of water from the degasser vent was observed. 
27. DISPOSAL SYSTEM PERFORMANCE

The reservoirs receiving the spent geothermal water performed as expected. Little change in discharge was required as a consequence of the geothermal project. Tables 3 and 4 show the water analysis of the three reservoirs affected by the geothermal project and a control reservoir. Although the water analyses varied considerably from beginning to ending of the project, in no case was the percentage increase for any reported species larger in the geothermal resevoirs than in the control resevoir. Consequently, no significant change in surface water quality was observed as a result of this project. 
TABLE 3 PRE-PROJECT WATER ANALYSES (8/8/78)

\begin{tabular}{|c|c|c|c|c|c|}
\hline \multirow[b]{2}{*}{ SPECIES } & \multirow{2}{*}{$\begin{array}{c}\text { GEOTHERMAL } \\
\text { WATER }\end{array}$} & \multicolumn{3}{|c|}{ RESERVOIR } & \multirow[b]{2}{*}{ C } \\
\hline & & 1 & 2 & 3 & \\
\hline C1 & 185 & 78 & 253 & 20 & 12 \\
\hline $\mathrm{SO}_{4}$ & 1087 & 602 & 166 & 338 & 204 \\
\hline $\mathrm{SiO}_{2}$ & 42 & 16 & 12 & 7 & 5 \\
\hline $\mathrm{HCO}_{3}$ & 126 & 138 & 80 & 100 & 112 \\
\hline $\mathrm{NO}_{3}$ & -- & 3.8 & 0.1 & 0.4 & 0.3 \\
\hline $\mathrm{Ca}$ & 381 & 146 & 92 & 100 & 46 \\
\hline $\mathrm{Mg}$ & 79 & 44 & 33 & 19 & 12 \\
\hline $\mathrm{Na}$ & 85 & 90 & 85 & 54 & 61 \\
\hline K & 15 & 32 & 75 & 7 & 8 \\
\hline $\mathrm{Fe}$ & 0.1 & 0.4 & 1 & 0.8 & 0.5 \\
\hline Mn & 0.4 & 0.2 & 0.2 & 0.2 & 0.2 \\
\hline Total Hard. & -- & 548 & 365 & 329 & 164 \\
\hline T.D.S. & 2066 & 1032 & 1232 & 538 & 356 \\
\hline $\mathrm{Cu}$ & -- & $<1$ & $<1$ & -- & $<1$ \\
\hline Pb & -- & $<1$ & $<1$ & -- & $<1$ \\
\hline $2 n$ & -- & $<0.2$ & $<0.2$ & -- & $<0.2$ \\
\hline cd & -- & $<0.1$ & $<0.1$ & -- & $<0.1$ \\
\hline $\mathrm{Ni}$ & -- & $<1$ & $<1$ & -- & $<1$ \\
\hline $\mathrm{Hg}$ & -- & $<0.002$ & $<0.005$ & -- & $<0.002$ \\
\hline pH & 6.92 & 7.97 & 9.16 & 8.3 & 8.78 \\
\hline
\end{tabular}

*All values ppm except pH 
TABLE 4 - Post-Project Water Analysis

$(7 / 26 / 82)$

\begin{tabular}{|c|c|c|c|c|}
\hline \multirow[b]{2}{*}{ SPECIES } & \multicolumn{3}{|c|}{ Reservoir* } & \multirow[b]{2}{*}{$C$} \\
\hline & $1 \neq$ & 2 & 3 & \\
\hline C1 & & 146 & 32 & 2.5 \\
\hline $\mathrm{SO}_{4}$ & & 1760 & 1060 & 1420 \\
\hline $\mathrm{SiO}_{2}$ & & -- & -- & - \\
\hline $\mathrm{HCO}_{3}$ & & 90 & 120 & 137 \\
\hline $\mathrm{NO}_{3}$ & & -- & -- & -- \\
\hline $\mathrm{Ca}$ & & 316.7 & 166.5 & 86 \\
\hline $\mathrm{Mg}$ & & 139.7 & 48.6 & 110 \\
\hline $\mathrm{Na}$ & & 321.8 & 92 & 287 \\
\hline$K$ & & 31.3 & 31 & 15.6 \\
\hline $\mathrm{Fe}$ & & 0.2 & 0.15 & 0.1 \\
\hline$M n$ & & - & -- & -- \\
\hline Total Hard & & 1865 & 615 & 668 \\
\hline T.D.S. & & 2926 & 1260 & 1814 \\
\hline $\mathrm{Cu}$ & & -- & -- & -- \\
\hline $\mathrm{Pb}$ & & -- & - & -- \\
\hline$Z n$ & & - & -- & - \\
\hline cd & & -- & -- & -- \\
\hline $\mathrm{Ni}$ & & -- & -- & -- \\
\hline $\mathrm{Hg}$ & & -- & -- & -- \\
\hline pH & & 8.37 & 8.08 & 9.06 \\
\hline
\end{tabular}

* All values in ppm except $\mathrm{pH}$

\# Abandoned 


\subsection{Performance Summary}

Pipeline delivered 170 gallons of geothermal fluid per minute as designed. However, during the first several weeks of operation it was observed that flow diminished with time. Repeated flushing of the line at the cleanouts along the low points of the lines improved the flow rate to some extent but lower than design flow rates were achleved. This was found to be the result of air pocket accumulation in the high points along the line. Correction of this problem is described in Section 28.3.

The pipeline supplying geothermal fluid requires no maintenance with the exception of bi-weekly flushing of the low points along the line. This requires only several minutes of an operator's time for clean out. The discharge from each cleanout is surface discharged. The only accumulation in the line is observed to be an iron pyrite material. No constriction of the line is observed to occur because of the accumulation of this material on the inside of the pipeline. This phenomena was observed prior to pipeline construction but observed not to present potential for line plugging.

\subsection{Data Acquisition}

Discharge rates from the pipeline were measured by volumetric displacement at the discharge points both at the grain dryer and beyond the shop heat exchanger. Total flow at the discharge points equaled the 170 gallon per minute design 1 imit. Temperatures at the discharge points were observed to be $151^{\circ} \mathrm{F}$ indicating a $2^{\circ} \mathrm{F}$ drop in temperature from the wellhead to the heat exchangers.

\subsection{Post Construction Modification}

The only modification in the transmission line consisted of installing air purge devices at two high points along the transmission line. The 
first high point was between the wellhead and the first cleanout, the second high point was between the first and second cleanout. Inexpensive PVC air vents were attached to the lines at these points. They have worked satisfactorily for three years since their installation and continue to perform satisfactorily. Although a high point in the transmission line exists between the second and third cleanouts, no air vent was placed on the line at that point. No difficulty in maintaining adequate flows through the transmission system has been observed in the absence of such an air vent. This indicates that the gas producing potential of the geothermal fluid is greatly diminished by the time the fluid reaches this point of the line. Apparently most of the gas produced by the geothermal fluid is the result of it existing at low pressure in the line and most of it is removed from the geothermal fluid at points near the well head.

\subsection{Operator Satisfaction}

The transmission system is far superior to the transmission system previously used by the Diamond Ring Ranch personnel for stock watering. The transmission system is reliable and is not subject to plugging as was the smaller previous line used by the personnel. The only difficulty in the transmission system exists at the discharge points for the transmission line. Both discharge points are fitted with large gate valves to control flow rates. These large gate valves have a propensity for corroding and becoming very difficult to operate. This requires either very frequent maintenance or as is the normal case, heating of the thread rod on the gate to free the valves. 


\subsection{Performance Summary}

The distribution system consisting of two closed hydronic loops for the space heating system was initially charged with water. This operated satisfactorily the first year of operation which was the winter of 1979-80. The original design concept included auxiliary power for recirculating the water through the distribution system to protect it from freezing in the case of power failure. During the first winter of operation, there was no power failure and the system operated normally. However, during the second winter of operation there were numerous power failures and considerable periods of inoperation leading to freezing of the lines. As a consequence many of the above ground lines had to be replaced during the summer of 1981 . This experience made it apparent that more than auxiliary power supplies would be required to protect the system from freezing. It was determined that a passive protection system was far superior to an active protection system requiring the presence of an operator. Consequently, it was determined that antifreeze must be $\mathrm{placed}$ in the distribution lines to assure the protection of the lines from freezing. This was installed in September of 1981 and no problem with freezing has occurred since.

\subsection{Data Acquisition}

There was no special instrumentation to obtain data from the distribution system.

\subsection{Post Construction Modification}

As described in Section 29.1, the distribution lines were filled with antifreeze in the summer of 1981 after experiencing severe freezing the previous winter. A second area of difficulty which required modification was leaking between the PVC pipe threads which fitted into the bronze circuit setters. With rare exception, all such fittings 
leaked. The leaking was the result of a poor match between the PVC pipe thread and the bronze circuit center. Although each joint had pipe compound on it, any twisting of the thread would cause leaking. Examination of this problem revealed that the threads on the PVC fitting bottomed out in the bronze circuit center and the only way to assure good fit was to cut off approximately one-half inch of the PVC pipe thread and rethread the system using teflon tape. It is recommended that special attention be given to this thread matching in future installations.

Some modification of heat exchange equipment and monitoring equipment in each space heating location required the shutting off of the geothermal circulation for access. It became apparent from such experiences that it should be specified in each such geothermal system that there be a main shut-off on both supply and return lines to each home or other space heated structure at the exterior of the building. On several occasions, it was necessary to remove the circuit centers and various heat monitoring equipment inside the space heating application structure resulting in a large discharge of water into the structure. Fortunately, this occurred only when the lines were charged with water. Had they been charged with antifreeze, cleanup of the spills would have been much more difficult. It should be noted that no such valves were added to this system.

\subsection{Operator Satisfaction}

The operator of the geothermal system was quite concerned initially about the possibility of freezing of the geothermal line. That concern was evident in their care of the system during the first heating season. During the second year, however, events conspired to cause freezing of the lines and subtantiating the concern. After the line was filled with antifreeze, operator satisfaction was greatiy improved and no particular dissatisfaction with the system has been expressed since. 
30. APPLICATION SYSTEM PERFORMANCE

30.1 Performance Summary

The application system consisted of the water-to-air heat exchangers located within the

$$
\begin{aligned}
& \text { owner's home } \\
& \text { employee's home } \\
& \text { two mobile homes } \\
& \text { shop } \\
& \text { hospital barn }
\end{aligned}
$$

and the grain dryer water-to-air exchanger. All of these exchangers performed as expected when the system was first operated. However, two major problems did appear in the system after initial operation. The first problem which arose was freezing of the water in the recirculating space heating system during periods of power failure. This freezing caused rupture of both exchangers in the mobile homes. These were removed and repaired with substantial difficulty. This problem. was rectified by adding approximately 1000 gallons of ethylene glycol $(30 \%)$ to the system.

The second major problem was the plugging of the flow meters by particles in the recirculating lines. Most of these particles were introduced when a line was inadvertently broken during excavation unrelated to this project. This plugging was eliminated by placing in-line screens before each flow meter.

\subsection{Data Acquistion}

Data acquisition consisted of monitoring the heat delivered to each structure receiving space heating. This was done using a model RS 805 Rho Sigma BTU meters. These meters performed satisfactory unt il blockages or freezing occurred in the lines. At that point, ranch personnel applied heat to some of the flow meters which melted the plastic rotors. The following data were obtained: 


\section{Table 5 Summary of Space Heat Replaced}

\begin{tabular}{|c|c|c|c|c|c|}
\hline Application & $\begin{array}{c}\text { Fuel } \\
\text { Replaced } \\
\end{array}$ & $\begin{array}{l}\text { Average } \\
\text { BTU's/Hr }\end{array}$ & Period & Degree Days & $\begin{array}{c}\text { Btu's } \\
\text { Annual Rate }\end{array}$ \\
\hline Owner's Home & e & 28,240 & $\begin{array}{l}2 / 11 / 82- \\
4 / 11 / 82\end{array}$ & 1860 & $1.66 \times 10^{8}$ \\
\hline Employee's H & Home & 11,220 & $\begin{array}{l}2 / 11 / 82 \\
4 / 11 / 82\end{array}$ & 1860 & $0.66 \times 10^{8}$ \\
\hline Shop & $\mathbf{P}$ & $94,818 \times 2$ & $\begin{array}{l}2 / 11 / 82- \\
2 / 25 / 82\end{array}$ & 584 & $8.21 \times 10^{8}$ \\
\hline Mobile Home & (Near) P & 5,929 & $\begin{array}{l}1 / 10 / 82 \\
2 / 10 / 82\end{array}$ & 1515 & $0.21 \times 10^{8}$ \\
\hline Mobile Home & (Far) $P$ & 5,929 & $\begin{array}{l}1 / 10 / 82 \\
2 / 10 / 82\end{array}$ & 1515 & $0.21 \times 10^{8}$ \\
\hline
\end{tabular}

Hospital Barn

\begin{tabular}{lllr} 
Milk House & $E$ & 7,719 & $0.23 \times 10^{8}$ \\
Barn & 0 & same as shop $\times 3$ & $12.30 \times 10^{8}$ \\
\hline
\end{tabular}

Total Space Heating Replaced

$23.5 \times 10^{8}$

E - electricity

P - propane

0 - fuel oil

Table 5 shows the fuel replaced by each application and the average heating rate supplied by the system over the period cited. During the given period, the number of degree heating days is also given. The annual rate was calculated by multiplying the heating rate by the hours in the period over which the rate was measured followed by multiplication by the ratio of annual degree heating days to degree 
heating days in the period. The degree heating days are based on $65^{\circ} \mathrm{F}$ and would be greater if based on $70^{\circ} \mathrm{F}$.

The BTU meter in the shop monitored only one of the two fan coil units. Therefore, the total heat supplied to the shop was assumed to be twice the heat supplied to the monitored fan coil unit. Likewise, the heat supplied to each of the three hospital barn fan coil units was assumed to be equal to the heat supplied to the shop fan coil unit. This is a good assumption since the fan coil units were identical and the ambient air temperatures in both structures comparable. The data for the exchange, located in the milk-house section of the hospital barn is the actual measured data.

\subsection{Post Construction Modification}

Post construction modifications were limited to the installation of screens in the lines before each BTU flow meter. A modification which should have been made but has not is the installation of screens around each fan coil unit in open areas such as the barn and shop to prevent birds from using them as nest sites. Such nest building caused the failure of at least two fan coil motors in the hospital barn.

30.4 Operator Satisfaction

The operator is satisfied with the system except for the continual plugging of the flow meters used to monitor BTU rates. Most of these meters by project's end were either jammed with particles or melted by use of heat in an attempt to free or thaw them. The operator was most impressed with the fact that the owner home was heated entirely by the geothermal system from February to April 1982. During this time the normal heat pump system was inoperable. 


\section{CONSTRUCTION COSTS}

\subsection{Production System}

The well for this project was drilled in 1959. It was valued at $\$ 90,000$ for the purpose of cost matching, but its replacement would cost approximately $\$ 250,000$. This is based on the cost of new wells at Phillip and Pierre.

\subsection{Disposal System}

The disposal system consisted of discharging the spent geothermal fluid into the disposal reservoirs. The portion of the construction contract required to route the discharge lines to the discharge points was approximately $\$ 8,123$. This includes the cost of shut-off valves of each discharge point.

\subsection{Transmission System}

The transmission system was bid as part of the total project and separate accounting was not made for the transmission line. However, estimates by the contractor were that approximately $\$ 63,753$ were spent constructing the transmission line. This includes the three cleanouts and the well head valves,

\subsection{Distribution. System}

Est imates by the prime contractor are that $\$ 47,920$ were spent constructing the distribution system. This includes all the piping to and from each application which carried the recirculating water. It does not include any of the costs of heat exchangers. If the waterwater plate heat exchangers are to be included in this figure, it should be increased by $\$ 19,542$.

\subsection{Application System}

The application system which consists of all of the heat exchangers 
(including the water-water plate exchangers) and control equipment cost approximately $\$ 39,944$. If the plate exchangers are placed in the distribution category, this figure should be reduced by $\$ 19,542$. 
32. OPERATING AND MAINTENANCE COSTS

\subsection{Operating Cost}

Operating costs for the geothermal system are incurred because of the need for electrical power for the recirculating pumps, the space heating pumps, and diesel fuel to drive the fan in the grain dryer. This fan is rotated by a power take off from a diesel tractor. The cost for each of these is summarized below.

\section{Table 6 Operating Costs}

\begin{tabular}{|c|c|}
\hline \multirow{2}{*}{\multicolumn{2}{|c|}{ Space Heating }} \\
\hline & \\
\hline recirculating pumps................. & 352 \\
\hline fan cotls..................... & 427 \\
\hline Grain Dryer & \\
\hline recirculating pump......... & 250 \\
\hline fan.. & 893 \\
\hline
\end{tabular}

These costs are based on $5 \mathrm{c} / \mathrm{kw} \mathrm{hr}$ and $\$ 3.11 / \mathrm{hr}$ to drive the fan which is powered by a diesel engine. The basis is the cost of operation for the period given. In the case of space heating, it takes into consideration the periodic demand for heating. On the other hand, the cost for operating the grain dryer is for continuous operation for one month.

32.3 Maintenance cost

32.3.1 Rout ine

Rout ine maintenance consists of the following:

a. monthly checking and filling recirculating fluid

b. monthly flushing of the transmission lines

c. monthly lubrication of recirculating pumps

d. annual cleaning and inspection of heat exchangers

e. perfodic change in flow discharge to match temperature. 
The value of the time required to perform these tasks is approximately $\$ 284$ per year.

\subsubsection{Major Component Repair or Replacement}

A major component repair and replacement schedule is not established over the short duration of the project. The only major failures during the course of this project were:

1) burned out fan coil motors in the hospital barn due to bird nests.

2) cracked heat exchangers in the mobile homes caused by freezing. The causes of both of these problems is rectified and similar failures are not expected.

The following schedule of replacement is estimated:

Frequency (years)

10

25
Replacement Item

transmission line vents

transmission line valve

new antifreeze

well head valve and piping

isolation heat exchangers

other grain dryer and space

heating radiators and exchangers
Cost $(\$)$

.324

221

1,500

861

19,542

8,520 
33. SYSTEM ECONOMICS

\subsection{Capital Costs}

Three different values were used for capital outlay in this analysis. In the first case a value of $\$ 256,000$ was used. This is the cash outlay for the Diamond Ring Ranch Project not including: (1) the sunk cost of the well which was originally drilled for stock watering and (2) the cost of equipment required regardless of heat source (air ducts, thermostats, grain dryer, etc.). The second case is the same as the first except the capital outlay was reduced by $\$ 64,000$ to show the impact of shortening the very long pipeline from the well to the ranch structures (4000 feet). Therefore, the resulting $\$ 190,000$ capital outlay represents the payback for a similar project with a well drilled for stock watering close to the ranch structures. The third case is for a capital outlay of $\$ 430,000$. This amount includes $\$ 240,000$ for a new well but assumes close proximity to the ranch structures as in the second case.

\subsection{Operating and Maintenance Costs}

Section 32 provides a detailed breakdown of the operating and maintenance costs. This section of the report determines an equivalent annual cost from these perlodic but sometimes non-annual costs. Below is a summary of the operating and maintenance cost schedule. 


\section{Table 7 Summary of Operating and Maintenance Costs}

Item Frequency

Space heating operation

annual 1

$\operatorname{cost}(\$)$

779

Grain dryer operation

annual

918U*

System Routine Maintenance

annual

284

Transmission line vents replaced 10 years 324

Transmission line valves replaced 10 years 221

New antifreeze installation

10 years

1,500

Well head piping and valve

replacement

25 years

861

Isolation heat exchangers

replacement

25 years

19,542

Grain dryer and space heating

radiators and exchangers

25 years

8,520

*U is equal to the number of months the grain dryer is operated annually.

The equivalent annual operating and maintenance cost determined from the costs in Table 7 depends on the time value of money. Table 8 presents the equivalent annual cost for selected interest rates.

Table 8 Equivalent Annual Operating and Maintenance Cost

Interest Rate(\%/year)

0

6

12

18
Equivalent Annual cost (\$)

$3202+918 U$

$4504+918 U$

$6013+9180$

$7709+918 v$

The most important fluctuating factor in determining system economics is the extent of grain dryer use. Such use has been atypical during the monitoring phase of this project because of the sale of Diamond Ring Ranch. In fact, no grain was planted in 1981-82. Even under normal economic conditions, use can vary widely with climatological factors which affect crop yields and moisture content. Also, management decisions about crop type and use can affect the extent of dryer use. Consequently, this analysis is performed as a function of grain dryer use. 
Fossil Fuel Requirements

Table 9 shows the space heating demands replaced by the geothermal system, the type of heating replaced, and the heat from fossil fuel required to satisfy these demands. The total annual value of the space heating fuel replaced is $\$ 26,793$.

Table 10 shows the total fuel savings as a function of grain dryer usage. The grain dryer replaced propane fuel. The cost of propane fuel per million BTU's used in these calculations was $\$ 10.75$. This value includes a 20 percent factor because the direct combustion of propane introduces water of combustion into the drying gas. This does not occur with geothermal heating.

\section{Table 9: Value of Space Heating Replaced}

\begin{tabular}{|c|c|c|c|c|}
\hline Source & Structure(s) & Annual BTU's & $\begin{array}{c}\text { Cost } \\
\left(\$ / 10^{6} \mathrm{BTU}\right)\end{array}$ & $\begin{array}{l}\text { Value } \\
(\$) \\
\end{array}$ \\
\hline Electricity & $\begin{array}{l}\text { Owner's Home } \\
\text { Milk House }\end{array}$ & $1.89 \times 10^{8}$ & 13.37 & 2,529 \\
\hline Propane & $\begin{array}{l}\text { Employee's Home } \\
\text { Shop } \\
\text { Mobil Homes }\end{array}$ & $9.29 \times 10^{8}$ & 10.75 & 9,989 \\
\hline Fuel 011 & Barn & $12.3 \times 10^{8}$ & 11.61 & 14,277 \\
\hline
\end{tabular}

Table 10: Total Fuel Savings Per Year

\begin{tabular}{ccc} 
Months of Grain & Value of Replaced & Total Fuel Savings \\
Dryer Usage & $\frac{\text { Grain Dryer Fuel }(\$)}{0}$ & $\frac{(\$)}{26,793}$ \\
\hline 0 & 21,672 & 48,465 \\
2 & 43,344 & 70,137
\end{tabular}

Since the operating cost of the geothermal system includes the cost of operating blowers and fans, the computation of savings by use of the geothermal system should include the abatement of costs for operating such blowers and fans. Table 11 summarizes these costs and tabula- 
tes total savings realized by the use of the geothermal system and its operation costs as cited.

Table 11: Total Savings Realized by the Use of the Geothermal System

\begin{tabular}{cccc}
$\begin{array}{l}\text { Months of } \\
\text { Grain Dryer }\end{array}$ & $\begin{array}{c}\text { Space Heating } \\
\text { Blower Savings } \\
\text { Usage }\end{array}$ & $\begin{array}{c}\text { Grain Dryer } \\
\text { Blower Savings } \\
\text { (\$-Electricity) }\end{array}$ & $\begin{array}{c}\text { Total } \\
\text { Savings }\end{array}$ \\
\hline 0 & 155 & 0 & $(\$)$ \\
2 & 155 & 1,786 & 26,948 \\
4 & 155 & 3,572 & 50,406 \\
& & & 73,864
\end{tabular}

33.4 Customer Billing - Not Applicable

33.5 Analysis

The payback period varies greatly with grain dryer usage and is also affected by the following factors:

- Method of financing

- Interest rate of financing

- Rate of inflation of energy cost

- Rate of return required on invested funds

- Capital outlay

- Maintenance and operation cost

Each of the following analyses is performed with different assumptions for these factors.

\subsubsection{Simple Payback}

Simple payback assumes that the entire cost is recovered through the savings realized by the project with no consideration given to interest rates, escalating fuel costs, or return on invested capital. Under this - the simplest of analyses - the following paybacks are determined for various grain dryer usages. 
Table 12: Simple Payback

Months of Grain Dryer

Usage Annually

0

2

4
Net Savings

Per Year $(\$)$

23,746

45,213

66,835
Simple Payback in

Years by Case

\begin{tabular}{|c|c|}
\hline I & II \\
\hline 10.8 & 8.1 \\
\hline 5.7 & 4.2 \\
\hline 3.8 & 29 \\
\hline
\end{tabular}

33.5.2 PON R\&D Analysis

Not applicable. This project was not analized in that study.

\subsubsection{Other Analyses}

The following analysis considers the entire project is financed at either 6,12 , or 18 percent interest per annum. The breakeven time is calculated as the point at which the benefits from the geothermal system equal the cost of installing, operating, and maintaining the geothermal system. Fuel savings are assumed constant. That is, it is assumed that conventional fuel costs remain constant. Table 13 shows the results of this analysis.

Table 13: Breakeven Time for Selected Interest Rates and 2 Months Grain Dryer Use Per Year

Interest Rate

(\% annum)

6

12

18
Breakeven Time in

Years by Case

\begin{tabular}{|c|c|}
\hline I & II \\
\hline 7.1 & 5.0 \\
\hline 10.0 & 6.3 \\
\hline & 8.7 \\
\hline
\end{tabular}




\section{REFERENCES}

1. Gries, J.P., Geothermal Applications on the Madison Aquifer System in South Dakota, Final Report, U.S. Energy Research and Development Administration, Contract No. EY-76-S-07-1625, 1977.

2. Andrichuk, J.M., Mississippian Madison Group Stratigraphy and Sedimentation in Wyoming and Southern Montana. Amer. Assoc. of Petrol. Geol. Bull., vol. 39, no. 11, Pp. 2170-2210, 1955.

3. Gries, J.P., and Mickelson, J.C., 1964, "Mississippian Carbonate Rocks of Western South Dakota and Adjoining Areas." In 3rd International Williston Basin Symposium, Pp. 109-118.

4. Craig, L.C., 1972, Mississippian System. In Geologic Atlas of the Rocky Mountain Region. Denver: Rocky Mountain Assoc. of Geol., 331 pp.

5. Crooks, T.J., 1968, Water Losses and Gains across the Pahasapa Limestone, Box Elder Creek, Black Hills, South Dakota. S. Dak. Acad. Sci. Proc., vol. 47, pp. 49-51.

6. Gries, J.P., and Crooks, T.J., 1968, "Water Losses to the Madison (Pahasapa) Limestone, Black Hills, South Dakota." Hyo. Geol. Ass'n Guidebook, 20th Ann. Field Conf., pp. 209-213.

7. Gries, J.P., 1971, Groundwater Potential of the Pahasapa Limestone. S. Dak. Acad. Sci. Proc,, vol. 50, pp. 61-65.

8. Gries, J.P., Niven, D.W., and Crooks, T.J., 1968, Recharge of the Pahasapa Limestone Aquifer from Stream Losses, Black Hills, South Dakota. S. Dak. Acad. Sci. Proc., vol. 47, pp. 56-61.

9. Rahn, P.H., and Gries, J.P., 1973, Large Springs in the Black Hills, South Dakota and Wyoming. S. Dak. Geol. Survey, Rept. Inves. 107, $46 \mathrm{pp}$. 
10. Rahn, P.H., personal communication.

11. Swenson, F.A., 1968, "New Theory of Recharge to the Artesian Basin of the Dakota." Geol. Soc. Amer. Bull., vol. 79, pp. 163-182.

12. Carda, D.D., 1975, A Study of the Radium Content of the Groundwaters in Western South Dakota with Emphasis on the Madison (Pahasapa) Limestone. Ph.D. dissertation, South Dakota School of Mines and Technology, $58 \mathrm{pp}$.

13. Eckert, E.R.G., and Drake, R.M., 1972, Analysis of Heat and Mass Transfer, McGraw-Hill Book Co., New York, P. 106. 